\title{
Products of abiotic U(VI) reduction by biogenic magnetite and vivianite
}

\author{
Harish Veeramani ${ }^{\text {a, } 1, *}$, Daniel S. Alessi ${ }^{\text {a }}$, Elena I. Suvorova ${ }^{a}$, \\ Juan S. Lezama-Pacheco ${ }^{\mathrm{b}}$, Joanne E. Stubbs ${ }^{\mathrm{b}}$, Jonathan O. Sharp ${ }^{\mathrm{a}, 2}$, Urs Dippon ${ }^{\mathrm{c}}$, \\ Andreas Kappler ${ }^{\mathrm{c}}$, John R. Bargar ${ }^{\mathrm{b}}$, Rizlan Bernier-Latmani ${ }^{\mathrm{a}}$ \\ ${ }^{a}$ Environmental Microbiology Laboratory, Ecole Polytechnique Fédérale de Lausanne (EPFL), Switzerland \\ ${ }^{\mathrm{b}}$ Stanford Synchrotron Radiation Lightsource (SSRL), USA \\ ${ }^{\mathrm{c}}$ Geomicrobiology, Center for Applied Geosciences (ZAG), Universität Tübingen, Germany
}

Received 20 September 2010; accepted in revised form 14 February 2011; available online 21 February 2011

\begin{abstract}
Reductive immobilization of uranium by the stimulation of dissimilatory metal-reducing bacteria (DMRB) has been investigated as a remediation strategy for subsurface U(VI) contamination. In those environments, DMRB may utilize a variety of electron acceptors, such as ferric iron which can lead to the formation of reactive biogenic Fe(II) phases. These biogenic phases could potentially mediate abiotic U(VI) reduction. In this work, the DMRB Shewanella putrefaciens strain CN32 was used to synthesize two biogenic $\mathrm{Fe}(\mathrm{II})$-bearing minerals: magnetite (a mixed $\mathrm{Fe}(\mathrm{II})-\mathrm{Fe}$ (III) oxide) and vivianite (an $\mathrm{Fe}(\mathrm{II})$-phosphate). Analysis of abiotic redox interactions between these biogenic minerals and U(VI) showed that both biogenic minerals reduced U(VI) completely. XAS analysis indicates significant differences in speciation of the reduced uranium after reaction with the two biogenic Fe(II)-bearing minerals. While biogenic magnetite favored the formation of structurally ordered, crystalline $\mathrm{UO}_{2}$, biogenic vivianite led to the formation of a monomeric U(IV) species lacking U-U associations in the corresponding EXAFS spectrum. To investigate the role of phosphate in the formation of monomeric U(IV) such as sorbed U(IV) species complexed by mineral surfaces, versus a U(IV) mineral, uranium was reduced by biogenic magnetite that was pre-sorbed with phosphate. XAS analysis of this sample also revealed the formation of monomeric U(IV) species suggesting that the presence of phosphate hinders formation of $\mathrm{UO}_{2}$. This work shows that $\mathrm{U}(\mathrm{VI})$ reduction products formed during in situ biostimulation can be influenced by the mineralogical and geochemical composition of the surrounding environment, as well as by the interfacial solute-solid chemistry of the solid-phase reductant.
\end{abstract}

(C) 2011 Elsevier Ltd. All rights reserved.

\section{INTRODUCTION}

Uranium mining and processing for nuclear weapons production has led to extensive uranium contamination of soil and groundwater at US Department of Energy (DOE) sites. Among options for remediating uranium-

\footnotetext{
* Corresponding author. Tel.: +1 5409225540.

E-mail address: harish@vt.edu (H. Veeramani).

${ }^{1}$ Current address: Department of Geosciences, Virginia Polytechnic Institute and State University, USA.

${ }^{2}$ Current address: Environmental Science \& Engineering, Colorado School of Mines, USA.
}

contaminated sites, in situ reductive bioremediation has received appreciable attention due to its perceived costeffectiveness when compared to pump-and-treat methods, and because it obviates the need for off-site handling of hazardous materials (Palmisano and Hazen, 2003). Hexavalent uranium [U(VI)], the valence state of contaminant uranium at most sites, is stable in oxic environments and typically occurs as aqueous carbonate complexes in oxic groundwater at circumneutral $\mathrm{pH}$. In contrast, tetravalent uranium [U(IV)], produced by biological or abiotic processes, is stable in anoxic environments and often occurs as the sparingly soluble mineral, uraninite $\left(\mathrm{UO}_{2}\right)$ (Langmuir, 1978). 
Subsurface uranium can be reduced by a number of abiotic (Behrends and Van Cappellen, 2005) and microbiallymediated processes (Abdelouas et al., 1998; Elias et al., 2003) including reductive immobilization of uranium by dissimilatory metal-reducing bacteria (DMRB) (Lovley, 1993). These bacteria catalyze U(VI) reduction using organic acids, alcohols or $\mathrm{H}_{2}$ as electron donors and utilize $\mathrm{Fe}(\mathrm{III})$ as growth-supporting electron acceptors.

Fe-oxides and iron-bearing clay minerals, which are widely distributed in soils and sediments, represent a large reserve of $\mathrm{Fe}$ (III) for DMRB (Kostka et al., 2002; Zachara et al., 2002; Kappler and Straub, 2005). This includes contaminated US-DOE sites where cleanup efforts are underway to immobilize uranium as uraninite (N'Guessan et al., 2008). Evidence from both field and laboratory studies also suggest a nexus between iron redox cycling and uranium redox processes (Galloway, 1978; Posey-Dowty et al., 1987). The biostimulation of DMRB will likely lead to biological Fe(III) reduction (Wielinga et al., 2000; Finneran et al., 2002; Anderson et al., 2003; Elias et al., 2004; ) and production of sorbed $\mathrm{Fe}(\mathrm{II})$ or $\mathrm{Fe}(\mathrm{II})$-bearing minerals as metabolic products. The $\mathrm{Fe}(\mathrm{II})$-bearing phases found include magnetite, siderite, vivianite, ferruginous smectite, and green rust (Bell et al., 1987; Roden and Zachara, 1996; Fredrickson et al., 1998; Zachara et al., 1998; Dong et al., 2000; Roh et al., 2003; O'Loughlin et al., 2007; Komlos et al., 2008; O'Loughlin et al., 2010). Sorbed Fe(II) and the $\mathrm{Fe}(\mathrm{II})$-bearing biogenic phases can provide a reservoir of reducing capacity where reduction of $\mathrm{U}(\mathrm{VI})$ may occur due to abiotic interactions (O'Loughlin et al., 2010). This process may compete with direct enzymatic microbial reduction of U(VI) (Fredrickson et al., 2000).

Although reduction of $\mathrm{U}(\mathrm{VI})$ by aqueous $\mathrm{Fe}(\mathrm{II})$ is thermodynamically favorable, it can be kinetically limited, often necessitating an appropriate adsorbent to react with aqueous $\mathrm{Fe}(\mathrm{II})$ and catalyze the reaction. Research thus far has demonstrated U(VI) reduction by $\mathrm{Fe}(\mathrm{II})$ sorbed onto a variety of iron oxides/oxyhydroxides (Charlet et al., 1998; Liger et al., 1999; Fredrickson et al., 2000; Jeon et al., 2004), $\mathrm{Fe}(\mathrm{II})$-containing natural sediments (Behrends and Van Cappellen, 2005; Jeon et al., 2005), Fe(II)-containing carboxyl-functionalized microspheres (Boyanov et al., 2007), Fe(II) sorbed on corundum (Regenspurg et al., 2009) and Fe(II) sorbed on montmorillonite (Chakraborty et al., 2010). These studies primarily consider surface catalyzed processes that involved either concomitant or sequential adsorption of aqueous Fe(II) and U(VI) species onto a solid phase adsorbent or mineral to mediate abiotic $\mathrm{U}(\mathrm{VI})$ reduction.

Likewise, U(VI) can adsorb directly onto Fe(II)-bearing minerals and undergo reduction by structurally bound $\mathrm{Fe}(\mathrm{II})$. For instance, chemogenic green rust and silicates including various micas as well as ferrous-bearing sulfide minerals such as galena and pyrite have been shown to adsorb and reduce U(VI) (Wersin et al., 1994; O'Loughlin et al., 2003; Ilton et al., 2004; Ilton et al., 2005; Ilton et al., 2006; Bruggeman and Maes, 2010).

Biogenic $\mathrm{Fe}(\mathrm{II})$-bearing minerals are of interest in the context of uranium redox cycling and bioremediation because they are formed under Fe-reducing conditions
(Behrends and Van Cappellen, 2005). Previous studies that focused on chemogenic analogs may not have accounted for important properties characteristic of biogenic minerals such as their nano-size and associated enhanced reactivity (O'Loughlin et al., 2003; Regenspurg et al., 2009). Two such minerals are biogenic magnetite and vivianite both of which have shown to be produced as an end product of microbial $\mathrm{Fe}(\mathrm{III})$ reduction and environmentally pertinent under $\mathrm{Fe}(\mathrm{III})$ reducing conditions (Fredrickson et al., 1998; Kostka et al., 2002).

Interactions between $\mathrm{U}(\mathrm{VI})$ and magnetite have received appreciable attention because magnetite is a ubiquitous, environmentally relevant ferrous-bearing oxide, a metabolic byproduct of bacterial respiration, and a corrosion product of steel with ramifications for nuclear waste repositories (Ishikawa et al., 1998; Dodge et al., 2002; Ilton et al., 2010). Microbial reduction of amorphous ferric oxyhydroxide $\left(\mathrm{Fe}(\mathrm{OH})_{3}\right)$ has been reported to induce the formation of magnetite (Bell et al., 1987; Lovley et al., 1987; Moskowitz et al., 1989; Zhang et al., 1997; Konhauser, 1998). Similarly, magnetite formation from the reduction of aqueous $\mathrm{Fe}$ (III) precursors catalyzed by sulfate-reducing microorganisms such as Desulfovibrio spp. has been reported (Sakaguchi et al., 1993; Sakaguchi et al., 2002). Magnetite formation has also been reported during biooxidation of $\mathrm{Fe}(\mathrm{II})$ coupled to denitrification (Chaudhuri et al., 2001). A number of studies have investigated the role of magnetite in uranium reduction and the findings varied greatly ranging from no observable reduction (Dodge et al., 2002) to clear evidence of reduction (Scott et al., 2005; Aamrani et al., 2007; O'Loughlin et al., 2010) to the formation of a mixed-valence U(IV)-U(VI) phase (Missana et al., 2003; Aamrani et al., 2007; Regenspurg et al., 2009) or the formation of U(V) (Ilton et al., 2010). The variation in findings is presumably linked to variability in morphology, specific surface area and phase stoichiometry (Gorski and Scherer, 2009, Gorski et al., 2010) of the magnetite used as well as differences in experimental conditions.

In phosphate-rich reducing environments, vivianite $\left(\mathrm{Fe}_{3}\left(\mathrm{PO}_{4}\right)_{2} \cdot 8 \mathrm{H}_{2} \mathrm{O}\right)$ is an important sink for dissolved $\mathrm{Fe}(\mathrm{II})$ and is considered a stable mineral due to its low solubility at neutral pH (Nriagu and Dell, 1974; Buffle et al., 1989; Manning et al., 1991; Al-Borno and Tomson, 1994; Viollier et al., 1997; Sapota et al., 2006). Under anoxic conditions, vivianite is very stable $\left(\mathrm{K}_{\mathrm{sp}}=10^{-36}\right.$; (Nriagu, 1972)) and can exert significant control over the geochemical cycles of $\mathrm{Fe}$ and $\mathrm{P}$. Vivianite has also been reported as an end product of bacterial $\mathrm{Fe}(\mathrm{III})$ reduction (Fredrickson et al., 1998; Zachara et al., 1998; Roh et al., 2007; Peretyazhko et al., 2010). To our knowledge, the role of biogenic vivianite in abiotic uranium reduction and subsequent immobilization has not been investigated.

Redox processes linking biogenic magnetite or vivianite and uranium were systematically investigated and the factors controlling the product of $\mathrm{U}(\mathrm{VI})$ reduction probed in the present study. Biogenic magnetite and vivianite were produced by Shewanella putrefaciens CN32 and characterized by scanning electron microscopy (SEM), transmission electron microscopy (TEM), X-ray powder diffraction (XRD) and Mössbauer spectroscopy. Their propensity to 
reduce aqueous uranyl species was investigated by a combination of wet chemistry analyses and X-ray absorption spectroscopy (XAS). Understanding differences in uranium speciation in the presence of various environmentally relevant biogenic $\mathrm{Fe}(\mathrm{II})$-bearing minerals is critical due to its potential implication for long-term U(IV) reactivity.

\section{MATERIALS AND METHODS}

\subsection{Cultures, media and solutions}

\subsubsection{Culture and media}

Microbial culturing was carried out according to standard microbiological procedures under aseptic conditions. A frozen stock culture $(50 \%$ glycerol) of $S$. putrefaciens CN32 was streaked on sterile Petri dishes containing Luria Bertani (LB) agar (AppliChem GmbH, Germany). Following a $24 \mathrm{~h}$ incubation at $30^{\circ} \mathrm{C}$, a single colony was picked, transferred to $10 \mathrm{ml}$ of sterile LB broth and incubated overnight (ca. $12 \mathrm{~h}$ ) at $30^{\circ} \mathrm{C}$. An aliquot of the broth was inoculated $(1 \%)$ into $100 \mathrm{ml}$ of LB broth in a baffled flask, which was incubated at $30^{\circ} \mathrm{C}$ in a shaker (Excella E32, New Brunswick Scientific, New Jersey, USA) for $6-8 \mathrm{~h}$ to obtain cells at the mid-logarithmic phase that was used for experiments. Iron reduction experiments were carried out in a minimal medium M4 (all media ingredients purchased from Acron Organics), the composition of which is tabulated in Table SC-1 of the supplementary content (SC). A liter of the medium was transferred to each of four 2-1 anoxic bottles and the headspace was purged with sterile nitrogen, sealed under slight positive pressure and autoclaved. Geobacter sulfurreducens (DSM 12127) was purchased from DSMZ (Deutsche Sammlung von Mikroorganismen und Zellkulturen $\mathrm{GmbH}$ ) as a live culture and cultured according to their recommendations.

\subsubsection{Solutions}

Unless indicated otherwise, sample preparation, experimental setup and procedures were conducted under strict anoxic conditions - either in serum bottles equipped with a butyl rubber septum and an aluminum crimp or inside an anoxic chamber with an atmosphere of $2.2 \% \mathrm{H}_{2}$ and $97.8 \% \mathrm{~N}_{2}$. All chemicals used were of ultrapure analytical grade. Stock solutions were boiled and purged for several hours with $\mathrm{N}_{2}$ before use. Glassware was soaked in $10 \%$ $\mathrm{HCl}$ overnight (ca. $14 \mathrm{~h}$ ) and washed five times with deionized water and MilliQ water, respectively prior to use.

\subsubsection{Hydrous ferric oxide ( $H F O$ ) synthesis}

A 1 liter solution of $0.5 \mathrm{M}$ ferric chloride (Sigma-Aldrich $\mathrm{GmbH}$, Germany) was placed on a magnetic stirrer and titrated drop-wise with $1 \mathrm{M} \mathrm{NaOH}$ until a $\mathrm{pH}$ of 6.5 was reached. The resulting precipitate was allowed to settle, resuspended in MilliQ water and centrifuged (Beckman Coulter Avanti J-26XP) at 10,000g. Water washing and centrifugation were repeated several times to remove residual chloride. The resulting pellet was re-suspended in $100 \mathrm{ml}$ of pure MilliQ water and sonicated (Branson Sonifier 150, Alys Technologies, Lausanne) briefly to break up large aggregates. An aliquot of HFO analyzed by X-ray diffraction (XRD) did not show significant diffraction peaks. The HFO suspension was stored at $4{ }^{\circ} \mathrm{C}$ and used within 4 days to prevent phase transformation. The HFO suspension was not sterilized due to the risk of crystallization and/or phase transformation at elevated temperature and pressure.

\subsubsection{Ferric citrate stock solution}

About $0.5 \mathrm{M}$ ferric citrate (Sigma-Aldrich) was dissolved in boiling water on a magnetic stirrer, cooled to room temperature, adjusted to $\mathrm{pH} 7$ with $\mathrm{NaOH}$, and autoclaved.

\subsubsection{Uranyl acetate solution}

Uranyl acetate powder was dissolved in MilliQ water resulting in a $20 \mathrm{mM}$ stock solution that was filter-sterilized $(0.2 \mu \mathrm{m}$ polyethersulfone (PES)), and stored in an amber colored bottle within the anoxic chamber atmosphere.

\subsection{Biological $\mathrm{Fe}(\mathrm{III})$ reduction}

M4 medium ( $1 \mathrm{~L}$ ) in a duplicate set of $2 \mathrm{~L}$ anoxic bottles was amended either with $\mathrm{HFO}$ or $\mathrm{Fe}(\mathrm{III})$-citrate to a concentration of approximately $50 \pm 5 \mathrm{mM}$ Fe(III). Sodium dihydrogen phosphate $\left(\mathrm{NaH}_{2} \mathrm{PO}_{4}\right)$ to a concentration of $5 \mathrm{mM}$ was added to medium containing $\mathrm{Fe}$ (III)-citrate to favor the formation of vivianite. A $1 \%$ inoculum of LBgrown mid-logarithmic phase culture of $S$. putrefaciens CN32 or G. sulfurreducens was added to each Fe(III) containing anoxic bottle mentioned above. The cultures were incubated on a rotary shaker $(140 \mathrm{rpm})$ at $30^{\circ} \mathrm{C}$ (InforsHT Multitron Standard). At timed intervals, $0.5 \mathrm{ml}$ of sample from anoxic bottles above was withdrawn using a sterile syringe and needle (pre-purged with sterile $\mathrm{N}_{2}$ ) and acidified using $0.5 \mathrm{ml}$ of $1 \mathrm{M} \mathrm{HCl}$ (incubated for 1 week). $\mathrm{Fe}(\mathrm{II})$ was measured using the ferrozine colorimetric assay as described by Stookey (1970) on a UV-vis spectrophometer (Shimadzu UV-2501PC).

\subsection{Characterization of $\mathrm{Fe}(\mathrm{II})$ phases}

After no further observable Fe(III) reduction, the biogenic magnetite and vivianite settled to the bottom of each anoxic bottle leaving bacterial cells mostly in suspension. Inside an anoxic chamber (COY Laboratory Products, Inc., Grass Lake, MI) the supernatant from each bottle was decanted and the remaining solid phase was resuspended in $100 \mathrm{ml}$ of anoxic MilliQ water that was loaded into gas-tight centrifuge bottles equipped with an O-ring. The bottles were centrifuged at $10,000 \mathrm{~g}$ for $10 \mathrm{~min}$. This washing procedure was repeated five times.

\subsubsection{X-ray powder diffraction (XRD)}

Inside the anoxic chamber, washed samples were applied to silicon "zero background" sample holders (PANalytical), which were sealed in gas-tight jars for transport to the XRD facility. Diffraction measurements were carried out using $\mathrm{Cu} \mathrm{K} \alpha$ radiation (X'Pert Pro MD - PANalytical) in Bragg-Brentano geometry with a start and end angle of $5 \% / 2 \theta$ and $90^{\circ} / 2 \theta$, respectively. A step size of 0.016 , a time 
per step of $3 \mathrm{~s}$ and a scan speed of $0.083^{\circ} \%$ were used. Qualitative analysis was done by using the X'Pert HighScore Plus software that enabled automatic background subtraction of the spectra.

\subsection{2. $B E T$}

Inside an anoxic chamber $2 \mathrm{ml}$ of each washed mineral suspension was centrifuged (Eppendorf Mini-spin) in microfuge tubes and the resulting pellets were dried at $30{ }^{\circ} \mathrm{C}$ using a heating block. The dried minerals were transferred into specific sample cells that were sealed with rubber caps to maintain anoxic conditions during transportation and instrument manipulation. The surface areas of the minerals were analyzed by a multi-point BET analyzer (Micromeritics Gemini 2360) using nitrogen as the probe gas. The estimated error in the measurement according to the manufacturer was ca. $5 \%$ (relative).

\subsubsection{Electron microscopy (EM)}

Samples for scanning electron microscopy (SEM) were prepared inside the anoxic chamber by loading dried, crushed and homogenized samples on a carbon film that was mounted on a standard aluminum stub and loaded into the scanning electron microscope (FEI XLF-30-FEG). The energy was set to $10-20 \mathrm{keV}$ and all images were captured in scanning mode. The specimens for transmission electron microscopy (TEM) examination were prepared on carboncoated copper grids (Quantifoil Micro Tools, GmbH Jena) and allowed to dry. The composition, structure and morphology of particles were examined by high-resolution transmission electron microscopy (HRTEM), scanning transmission electron microscopy (STEM) imaging and $\mathrm{X}$-ray energy dispersive spectrometry (EDS) chemical microanalysis (INCA, Oxford) in a FEI CM300UT FEG transmission electron microscope $(300 \mathrm{kV}$ field emission gun, $0.65 \mathrm{~mm}$ spherical aberration, and $0.17-\mathrm{nm}$ resolution at Scherzer defocus). The images were recorded on a Gatan 797 slow scan CCD camera with a $1024 \times 1024$ pixels/14 bit detector and processed with the Gatan S5 Digital Micrograph 3.11.0 software including Fourier filtering. Low dose illumination conditions were used to record the images in order to prevent sintering of particles under the electron beam. The phase composition was determined by analyzing selected area electron diffraction (SAED) patterns and fast Fourier transforms of HRTEM images on the micrometer and nanometer scale, respectively. The interpretation of HRTEM images, SAED patterns and diffractograms were performed according to the method described by Veeramani et al. (2009) using the known electron-optical parameters and crystallographic data for several phases containing iron or uranium (ICSD 2003). Briefly, the interpretation of electron diffraction patterns was based on the spacing of the diffraction rings. Electron diffraction patterns were indexed by the standard ratio method, in which sample patterns were compared to patterns for specific crystal structure using the JEMS (EMS Java version) software package (Stadelmann, 1987). The usual accuracy of the calibration was ca. $1-2 \%$.

The size of the biogenic Fe(II) phase particles was estimated using Fourier filtered HRTEM images of agglomerated and non-agglomerated particles observed with various masks for better viewing the edges of particles.

\subsubsection{Mössbauer spectroscopy}

Samples were prepared inside an anoxic chamber by filtering the mineral suspensions through $0.45 \mu \mathrm{m}$ pore-size filters (MF-Millipore Membrane, mixed cellulose esters, Hydrophilic, $13 \mathrm{~mm}$ ). Filters containing the retained solids were sealed using Kapton tape and transported under anoxic conditions to the spectrometer (Wissenschaftliche Elektronik GmbH, Germany). Samples were mounted in a closed-cycle helium cryostat (Janis Research Company, Inc., USA) that allowed cooling of the sample to $5.5 \mathrm{~K}$. Mössbauer spectra were collected in transmission mode using a ${ }^{57} \mathrm{Co}$ source embedded within a Rhodium matrix. The source was operated at room temperature using a constant acceleration drive system set to a velocity range of $\pm 12 \mathrm{~mm} / \mathrm{s}$ with movement error of $<1 \%$. The absorption was recorded using a proportional counter and a 1024multichannel analyzer. The spectra were calibrated against a room temperature spectrum of alpha-Fe metal foil. Folding and fitting of the spectra was performed using Recoil software suite (University of Ottawa, Canada). All models except vivianite $(5.5 \mathrm{~K})$ were modeled using Voigt based spectral lines.

\subsection{Abiotic uranium reduction}

The molar Fe:U ratio was varied systematically by modifying the volume of magnetite suspension of known concentration transferred to tubes containing $40 \mathrm{ml}$ of anoxic MilliQ water. This ratio was varied to determine its effect on uranium reduction and speciation. The nomenclature of samples in these experiments is indicated as BioMagX or BioVivX, where $\mathrm{X}$ is the concentration ratio of iron to uranium. For example, BioMag50 refers to an experiment involving $50 \mathrm{mM}$ biogenic magnetite that was incubated with $1000 \mu \mathrm{M} \mathrm{U}(\mathrm{VI})$. The ratio of Fe: $\mathrm{U}$ in case of biogenic vivianite was set to $50: 1$ due to limitations in producing substantial quantities of the mineral. All the resulting suspensions were amended with $20 \mathrm{mM}$ (final concentration) anoxic PIPES buffer set to $\mathrm{pH} 7$ (AppliChem $\mathrm{GmbH}$, Germany). Parallel control mixtures with pasteurized minerals $\left(80^{\circ} \mathrm{C}\right.$ for $\left.20 \mathrm{~min}\right)$ were carried out in the presence and absence of bicarbonate $(1 \mathrm{mM})$ in a similarly buffered matrix. Uranium reduction was initiated by amending the suspensions with $1 \mathrm{mM} \mathrm{U}(\mathrm{VI})$ from a sterile stock solution of $20 \mathrm{mM}$ uranyl acetate (Sigma-Aldrich $\mathrm{GmbH}$ ). To investigate the effects of inorganic phosphate on uranium reduction and speciation, $463 \mathrm{mg}$ of biogenic magnetite $(50 \mathrm{mM}$ total $\mathrm{Fe}$ ) was equilibrated in $40 \mathrm{ml}$ of $100 \mathrm{mM}$ dihydrogen sodium phosphate overnight. The concentration of phosphate in the supernatant was analyzed by inductively coupled plasma optical emission spectroscopy (ICP-OES) before and after equilibration. Following a single anoxic MilliQ water wash of a pellet of magnetite onto which phosphate was adsorbed, uranium reduction was performed as mentioned above. All experiments were carried out in duplicates at $25 \pm 1^{\circ} \mathrm{C}$ under strictly anoxic conditions in the dark except for short-term exposure to 
light during sampling. Two samples $(0.5 \mathrm{ml}$ each $)$ were withdrawn at every time point from each anoxic bottle. One sample set was filtered through a syringe filter $\left(0.2 \mu \mathrm{m}\right.$ PES), amended with oxic $1 \% \mathrm{HNO}_{3}$ and analyzed for aqueous $\mathrm{U}(\mathrm{VI})$ using a Kinetic phosphorescence analyzer (KPA) (Chemchek Instruments, Inc.). This measurement targeted the disappearance of hexavalent uranium from solution. The second sample set was treated with an anoxic solution of $0.5 \mathrm{M}$ bicarbonate (final concentration), stored at $25^{\circ} \mathrm{C}$ overnight, filtered anoxically through a $0.2 \mu \mathrm{m}$ pore size filter and analyzed using the KPA as above. This sample treatment procedure enabled preferential de-sorption of U(VI) from the mineral surface (due to formation of uranyl carbonate complexes) and the analysis of the bicarbonate extract revealed the amount of adsorbed uranyl species. The amount of U(VI) reduced could be calculated by subtracting the amount of U(VI) recovered from the total amount of $U$ associated with the solid phase.

\subsection{Biological $\mathrm{U}(\mathrm{VI})$ reduction}

Batch enzymatic U(VI) reduction was carried out by $S$. putrefaciens $\mathrm{CN} 32$ and $G$. sulfurreducens under nongrowth conditions. These experiments were performed in a simple chemical matrix according to the method described by Sharp et al. (2009).

\subsection{X-ray absorption spectroscopy (XAS)}

Samples were prepared and shipped via express overnight courier service to SSRL (Stanford Synchrotron Radiation Light-source) for XAS analysis in septum bottles to maintain a hermetic seal. Prior to shipping, septum-bottles containing the samples were placed inside of a gas-tight stainless steel anoxic jar (Schutt biotech $\mathrm{GmbH}$, Göttingen, Germany) inside the anoxic chamber. XAS analysis included X-ray absorption near edge structure (XANES) and extended X-ray absorption near edge structure (EXAFS). All sample manipulation at SSRL was performed under an anoxic atmosphere $(2-5 \%$ hydrogen, balance nitrogen). Centrifuged wet samples were loaded in Al sample holders with Kapton windows. Anoxic samples were stored wet until analysis. $\mathrm{U} \mathrm{L}_{\mathrm{III}}$-edge transmission spectra at liquid nitrogen temperature $(77 \mathrm{~K})$ were collected at SSRL beamlines 4-1, using a $\mathrm{Si}$ (2 20 ) double-crystal monochromators. Beam line resolution was controlled by vertical beam dimensions to insure that the energy resolution was smaller than the intrinsic $\mathrm{U} \mathrm{L}_{\mathrm{III}}$-edge line width. EXAFS spectra were background subtracted, splined and analyzed using the Athena program (Ravel and Newville, 2005). Backscattering phase and amplitude functions required for fitting of spectra were obtained from FEFF8 (Rehr et al., 1992).

\section{RESULTS}

\section{1. $\mathrm{Fe}(\mathrm{III})$ reduction}

Iron reduction was observed in S. putrefaciens cultures amended with hydrous ferric oxide (HFO) and $\mathrm{Fe}(\mathrm{III})$

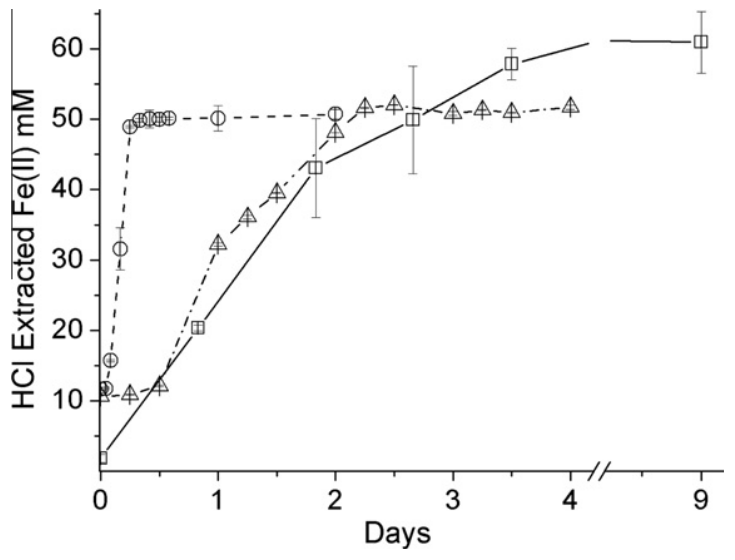

Fig. 1. ( $\square$ ) HFO reduction by $S$. putrefaciens, (O) Fe(III)-citrate reduction by $S$. putrefaciens, $(\Delta) \mathrm{Fe}(\mathrm{III})$-citrate reduction by $G$. sulfurreducens.

citrate and $G$. sulfurreducens cultures amended with $\mathrm{Fe}(\mathrm{III})$ citrate. However, the rates of $\mathrm{Fe}(\mathrm{III})$ reduction differed (Fig. 1). While the reduction of Fe(III)-citrate by $S$. putrefaciens reached a plateau in $24 \mathrm{~h}$, HFO reduction by the same bacterium occurred over the course of 9 days. G. sulfurreducens reduced $\mathrm{Fe}(\mathrm{III})$ citrate in about $50 \mathrm{~h}$. $\mathrm{Fe}(\mathrm{III})$ reduction by all cultures was assumed to be complete when steady-state $\mathrm{Fe}$ (II) concentration as measured by the ferrozine assay was reached. HFO reduction by $S$. putrefaciens $\mathrm{CN} 32$ resulted in a black precipitate while reduction of $\mathrm{Fe}(\mathrm{III})$-citrate by both cultures in the presence of phosphate produced a grayish white precipitate.

\subsection{Characterization of biogenic $\mathrm{Fe}(\mathrm{II})$ phases}

\subsubsection{BET}

Surface area analysis indicated that the specific surface area (SSA) of biogenic magnetite $\left(53.63 \pm 2.68 \mathrm{~m}^{2} / \mathrm{g}\right)$ was approximately eight times greater than that of biogenic vivianite $\left(7.66 \pm 0.38 \mathrm{~m}^{2} / \mathrm{g}\right)$ (both originating from $S$. putrefaciens). The SSA of biogenic vivianite produced by $G$. sulfurreducens was not determined due to difficulties in producing a sufficient amount of the mineral for analysis.

\subsection{2. $X R D$}

Qualitative background-subtracted XRD analysis (Fig. 2) confirmed the resultant crystalline biogenic $\mathrm{Fe}(\mathrm{II})$-bearing phases (originating from $S$. putrefaciens) to be magnetite and vivianite. Similarly the resultant Fe(II) phase produced by $G$. sulfurreducens was confirmed to be vivianite. XRD analyses did not show indications of secondary phases.

\subsubsection{Chemical characterization}

An aliquot of HFO was digested with concentrated nitric acid prior to reduction and analyzed for total iron. Comparing the amount of total iron to the steady-state $\mathrm{Fe}(\mathrm{II})$ concentration following $\mathrm{HFO}$ reduction yielded an $\mathrm{Fe}(\mathrm{II}): \mathrm{Fe}_{\text {Total }}$ ratio of $0.3 \pm 0.02$ for magnetite, consistent with the findings of Ilton et al. (2010). 


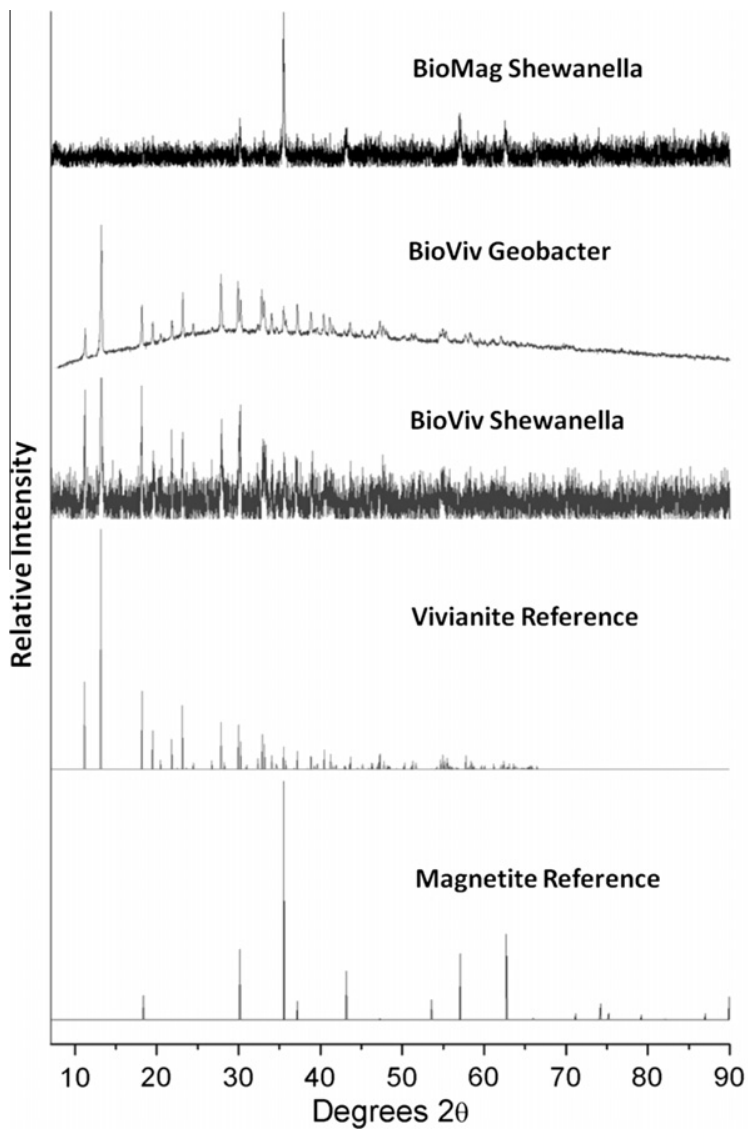

Fig. 2. XRD - Biogenic Magnetite and Vivianite. The difference in background between two vivianite samples could be due to the extreme reactivity of the Shewanella produced vivianite. All samples were analyzed under identical conditions.

\subsubsection{Electron microscopy}

Electron microscopy revealed that biogenic magnetite was agglomerated into micron and submicron-sized clumps comprised of individual particles of about $10 \mathrm{~nm}$ in diameter (Fig. 3). Selected area electron diffraction (SAED) of biogenic magnetite was found to be consistent with the structure of magnetite. Electron diffraction patterns taken from agglomerates showed traces of goethite. Electron microscopy of biogenic vivianite from $S$. putrefaciens $\mathrm{CN} 32$ (Fig. 3) revealed an average particle size in the sub-micron to micron range. The $\mathrm{Fe} / \mathrm{P}$ ratio was close to 1.5 in all EDS spectra suggesting a stoichiometric formula of $\mathrm{Fe}_{3}\left(\mathrm{PO}_{4}\right)_{2}$. Although rings in the electron diffraction pattern were broad, the diffuse ring close to the center is consistent with vivianite. The biogenic vivianite was shown to possess two different morphologies suggestive of phosphoferrite co-existing with vivianite. Phosphoferrite $\left[\mathrm{Fe}_{3}^{++}\left(\mathrm{PO}_{4}\right)_{2} \cdot 3\left(\mathrm{H}_{2} \mathrm{O}\right)\right]$ is chemically similar to vivianite $\left[\mathrm{Fe}^{++}{ }_{3}\left(\mathrm{PO}_{4}\right)_{2} \cdot 8\left(\mathrm{H}_{2} \mathrm{O}\right)\right]$ but with a different hydration state. Both, biogenic vivianite and phosphoferrite exhibit similar symmetry and diffraction patterns. This was consistent with X-ray powder diffraction data (Fig. 2) that indicated peaks corresponding to vivianite without secondary phases. The biogenic vivianite was extremely reactive and oxidized quickly upon brief exposure to air. In addition, electron microscopy did not reveal the presence of bacteria in the biogenic magnetite and biogenic vivianite samples, suggesting efficient separation of bacteria from the biogenic minerals during the washing procedure.

\subsubsection{Mössbauer spectroscopy}

Mössbauer analysis of biogenic magnetite at 245, 77 and $5 \mathrm{~K}$ confirmed that the most abundant iron phase in the sample was magnetite (about $48 \%$ of the total iron) (Fig. 4). However, the peaks of the spectra were broadened compared to highly crystalline synthetic magnetite. The peak broadening indicates small particle sizes in the submicron range. The $\mathrm{Fe}(\mathrm{II}): \mathrm{Fe}_{\text {Total }}$ ratio of the magnetite phase was determined as $0.28( \pm 1.5 \%)$ consistent with the wet chemistry analysis as described in Section 3.2.3 above (Table SC-2).

Besides magnetite, a poorly crystalline, unidentified iron phase exhibiting a strongly broadened magnetic sextet with a very low hyperfine field $(\mathrm{H})$ of $34.8 \mathrm{~T}$ was detected at $245 \mathrm{~K}$. For this phase, it was not possible to resolve the two sub models for iron at tetrahedral and octahedral lattice sites typical for magnetite. Similar results have been reported by Goya et al. (2003) and Corr et al. (2004) for synthetic, nanoparticulate $(<10 \mathrm{~nm})$ magnetite. However, the small $\mathrm{H}$ is not unique to nano-magnetite and could also correspond to other small particle sizes and/or phases with low crystallinity, consistent with nano-goethite phases as reported by Van der Zee et al. (2003) and Thompson et al. (2006) and. Siderite was detected as the third mineral phase in the sample (ca. 10\%).

Measurements at $77 \mathrm{~K}$ also indicated an unidentified nanoparticulate iron species that could not be resolved. The hyperfine field corresponding to the iron phase increases to $39 . \mathrm{T}$, again consistent with nanoparticulate phases. The magnetite phase could be confirmed at $77 \mathrm{~K}$. The iron(II) phase in the $77 \mathrm{~K}$ spectrum could be interpreted as siderite, consistent with the analysis at $245 \mathrm{~K}$. The spectra at $77 \mathrm{~K}$ spectra also showed broader peaks compared to those of highly crystalline samples, typical for small particle sizes that have previously been referred to as 'collapsed sextet' (Van der Zee et al., 2003; Thompson et al., 2006).

At $5 \mathrm{~K}$, the $\mathrm{H}$ field of the nanoparticulate $\mathrm{Fe}(\mathrm{III})$ phase increases to values in the range of magnetite (36-52 T) and cannot be resolved due to overlapping features. All peaks are broad, which is typical for small particles. Since siderite splits into eight peaks at $5 \mathrm{~K}$, the peak intensity became too small to be modeled.

We conclude that the biogenic magnetite phase is a relatively complex mixture dominated by magnetite $(\sim 50 \%)$ but including significant contributions from other nano crystalline iron phases (such as goethite as indicated by electron microscopy) and some contribution $(\sim 10 \%)$ from siderite.

Mössbauer analyses of biogenic vivianite (Fig. 4) at 245, and 77 and $5 \mathrm{~K}$ spectra were found to match well with $\mathrm{Fe}(\mathrm{II})$-phosphate references. Measurements carried out at 245 and $77 \mathrm{~K}$ indicated a single phase featuring two Fe(II) lattice sites, suggesting homogeneity in the sample. 
A

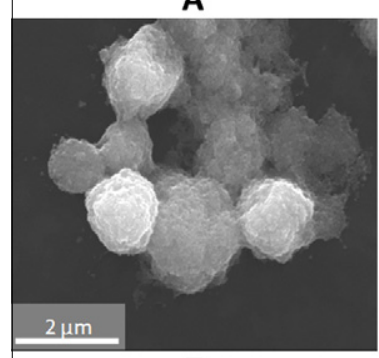

E

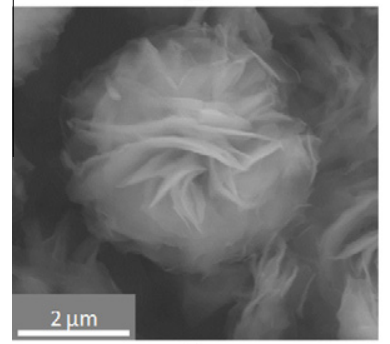

I

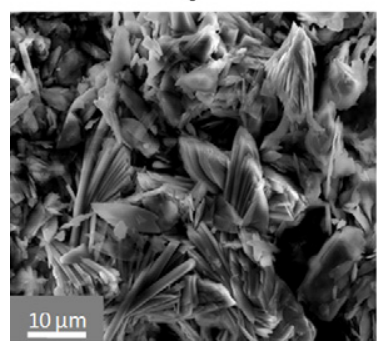

B

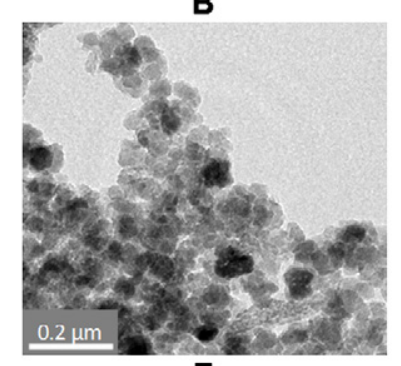

$\mathbf{F}$

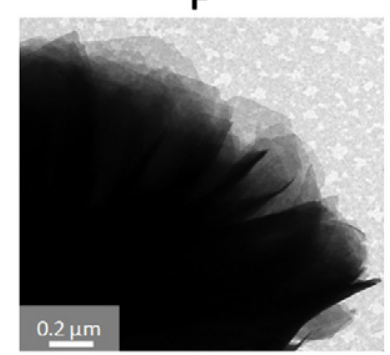

J

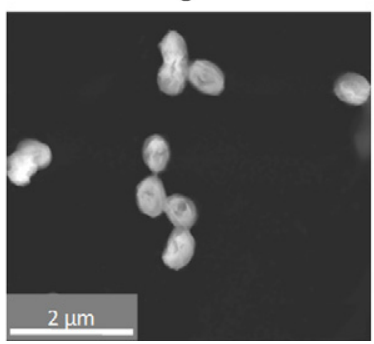

C

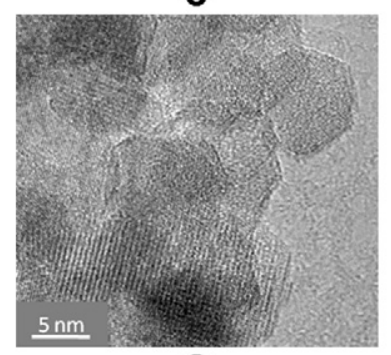

G
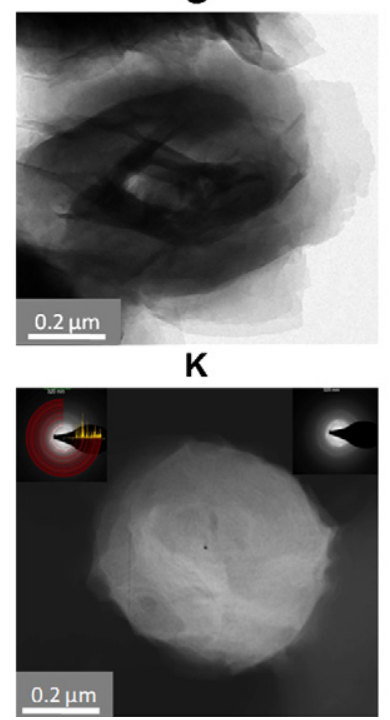

D

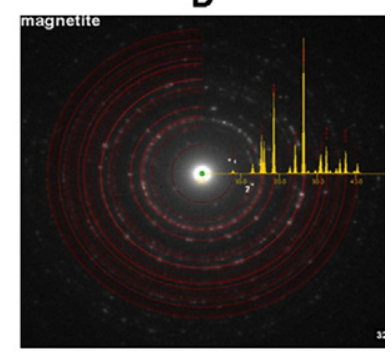

H

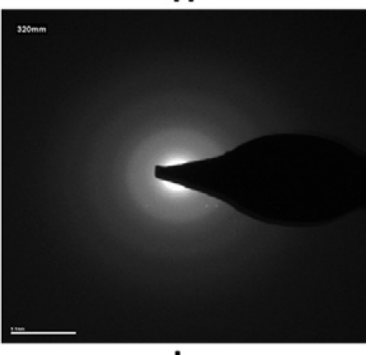

$\mathbf{L}$

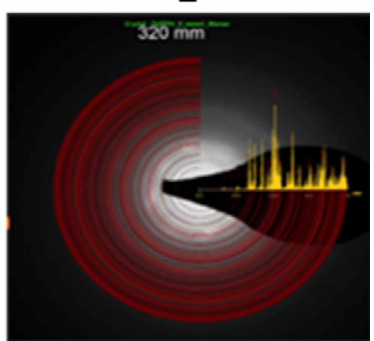

Fig. 3. (A-D) S. putrefaciens-derived biogenic magnetite: secondary electron SEM, dark-field STEM, HRTEM and SAED, respectively; (E-H) S. putrefaciens-derived biogenic vivianite: secondary electron SEM, dark-field STEM, darkfield STEM and SAED, respectively; (I-L) G. sulfurreducens-derived biogenic vivianite: secondary electron SEM, darkfield STEM, dark-field STEM and SAED, respectively.

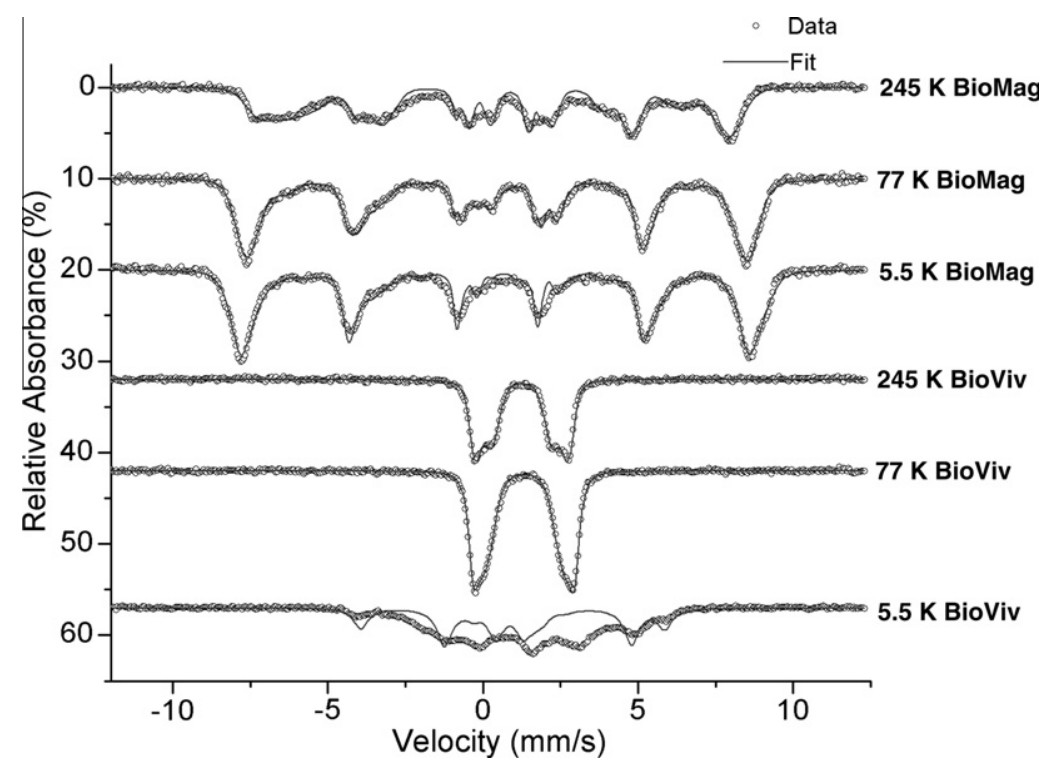

Fig. 4. Mossbauer spectra at various temperatures showing biogenic magnetite and vivianite, both derived from S. putrefaciens. (Data represented by open circles and model represented by grey solid lines).

Mössbauer analysis of the biogenic vivianite sample suggested the material to be at least partially dehydrated.
The spectra do not show the typical asymmetry of vivianite spectra (Forsyth et al., 1970; Mattievich and Danon, 1977; 
McCammon and Burns, 1980). The isomer shift (CS) and quadrupole splitting values provided satisfactory fits for phosphoferrite, $\left[\mathrm{Fe}_{3}\left(\mathrm{PO}_{4}\right)_{2} \cdot 3 \mathrm{H}_{2} \mathrm{O}\right]$ (Mattievich and Danon, 1977). The large quadrupole splitting of $>3 \mathrm{~mm} / \mathrm{s}$ of one of the doublets, however, is inferred to be a strong indication of vivianite (Table SC-3).

The peaks in the $5 \mathrm{~K}$ spectrum matched vivianite references well in general, although peak intensities were variable and the entire spectrum included a strong background (Fig. 4). This is suggestive of the presence of a single nanoparticulate phase. Due to the incomplete splitting, the spectrum obtained at $5 \mathrm{~K}$ could not be modeled quantitatively.

\subsection{Uranium reduction}

$\mathrm{U}(\mathrm{VI})$ amended to suspensions of biogenic magnetite or vivianite disappeared from solution rapidly (1-4 h), suggesting a rapid sorption process but not necessarily reduction (Fig. SC-1). To probe the extent of mineral-associated U reduction, samples from the suspension were treated with bicarbonate which recovered $\mathrm{U}(\mathrm{VI})$ but not $\mathrm{U}(\mathrm{IV})$ from the surface. This was confirmed by kinetic phosphorescence analysis (KPA) that is specific for hexavalent uranium. The rate of uranium reduction increased with increasing $\mathrm{Fe}: \mathrm{U}$ ratio in the magnetite system (Table 1, Fig. SC-2). In addition, reduction was observed in both pasteurized and unpasteurized suspensions (Figs. 5 and 6), suggesting an abiotic process. Graphs evidencing $\mathrm{U}(\mathrm{VI})$ reduction were plotted as micromoles of sorbed U(VI) per $\mathrm{m}^{2}$ of surface area (Figs.

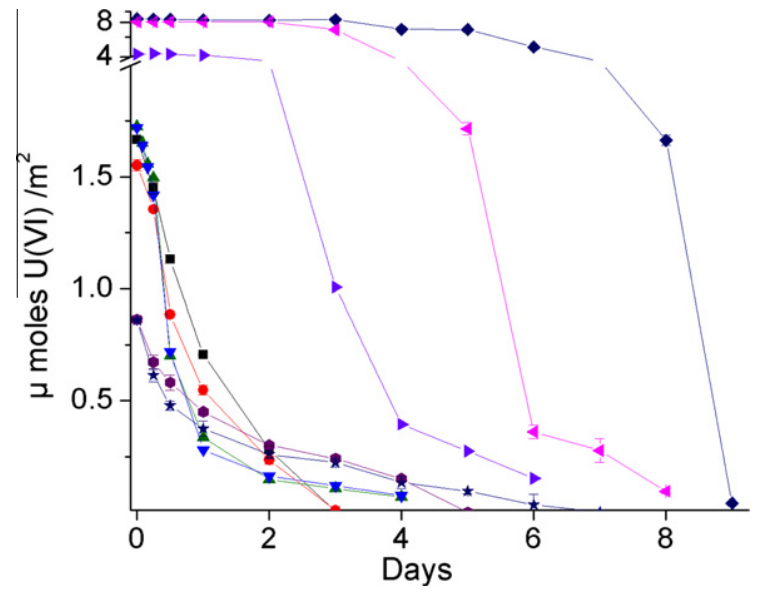

Fig. 5. Surface area normalized reduction of U(VI) by (0) BioMag100 + $1 \mathrm{mM}$ bicarbonate, $(\star)$ BioMag100 without bicarbonate, (ם) BioMag50 + $1 \mathrm{mM}$ bicarbonate, (@) BioMag50 without bicarbonate $(\mathbf{\Delta})$ Pasteurized BioMag $50+1 \mathrm{mM}$ bicarbonate, $(\nabla)$ Pasteurized BioMag50 without bicarbonate, $(\triangleright)$ BioMag20 without bicarbonate $(\diamond)$ BioMag10 $+1 \mathrm{mM}$ bicarbonate, (४) Pasteurized BioMag10 $+1 \mathrm{mM}$ bicarbonate.

5 and 6). Adsorbed U(VI) decreased over time as the reduction of sorbed U(VI) to surface-associated U(IV) proceeded. The rate of reduction followed a first-order reaction model (Figs. SC-2 and SC-3), which was used to determine rate constants and half-lives of the reaction (Table 1). For magnetite at low Fe: $\mathrm{U}$ ratios $(10: 1$ and $20: 1)$, reduction rates

Table 1

Summary of experimental conditions, sample descriptions and rates of abiotic uranium reduction by biogenic magnetite and vivianite. BioMag100, BioMag50, BioMag20, BioMag10 and BioMag2 refer to biogenic magnetite incubated with U(VI) at a Fe:U ratio of 100:1, 50:1, 20:1, 10:1 and 2:1, respectively. BioViv50 refers to biogenic vivianite incubated with U(VI) at a Fe:U ratio of 50:1. Sample marked with an asterisk indicate the presence of $1 \mathrm{mM}$ bicarbonate. + Extracted with $100 \mathrm{mM}$ bicarbonate. ND - Not determined. $\mathrm{pH}$ was verified before and after the experiment $(12 \mathrm{~h})$ and was found to drift insignificantly $( \pm 0.02)$.

\begin{tabular}{|c|c|c|c|c|c|c|c|}
\hline Sample & $\begin{array}{l}\text { Solids } \\
(\mathrm{mg})\end{array}$ & $\begin{array}{l}\text { Molar ratio } \\
(\mathrm{Fe}: \mathrm{U})\end{array}$ & $\begin{array}{l}\text { Bicarbonate } \\
\text { conc }(\mathrm{M})\end{array}$ & $\begin{array}{l}\text { Effective surface } \\
\text { area }\left(\mathrm{m}^{2}\right)\end{array}$ & $\begin{array}{l}K_{\text {obs }} \\
\left(\mathrm{h}^{-1}\right)\end{array}$ & $\begin{array}{l}\text { Half life } \\
\text { (h) }\end{array}$ & $r^{2}$ \\
\hline \multicolumn{8}{|l|}{ Biogenic magnetite } \\
\hline \multicolumn{8}{|l|}{ Unpasteurized } \\
\hline BioMag $100^{*}$ & 926 & $100: 1$ & 0.001 & 49.29 & 2.52 & 0.27 & 0.99 \\
\hline BioMag100 & 926 & $100: 1$ & 0 & 49.29 & 3.28 & 0.21 & 0.99 \\
\hline BioMag50* & 463 & $50: 1$ & 0.001 & 24.64 & 0.98 & 0.70 & 0.99 \\
\hline BioMag50 & 463 & $50: 1$ & 0 & 24.64 & 0.87 & 0.79 & 1.00 \\
\hline BioMag20 & 185.23 & $20: 1$ & 0 & 9.85 & 0.69 & 0.99 & 0.98 \\
\hline BioMag10 & 92.61 & $10: 1$ & 0 & 4.92 & 0.33 & 2.05 & 0.91 \\
\hline BioMag2* & 18.52 & $2: 1$ & 0.001 & 0.98 & 0.14 & 4.95 & 0.96 \\
\hline \multicolumn{8}{|l|}{ Pasteurized } \\
\hline BioMag50 & 463 & $50: 1$ & 0 & 24.64 & 0.58 & 1.17 & 0.99 \\
\hline BioMag50* & 463 & $50: 1$ & 0.001 & 24.64 & 0.77 & 0.89 & 0.99 \\
\hline BioMag10* & 92.61 & $10: 1$ & 0.001 & 4.92 & 0.81 & 0.85 & 0.96 \\
\hline BioMag50+P* & 436 & $50: 1$ & 0.001 & 24.64 & $0.38 \mathrm{f}$ & 1.81 & 0.98 \\
\hline \multicolumn{8}{|l|}{ Biogenic vivianite } \\
\hline BioViv50 (Shewanella Pasteurized) & 250 & $50: 1$ & 0.001 & 1.90 & $0.19 \mathrm{f}$ & 3.64 & 0.98 \\
\hline BioViv50 (Shewanella) & 250 & $50: 1$ & 0.001 & 1.90 & $0.11 \mathrm{f}$ & 6.30 & 0.95 \\
\hline BioViv50 (Geobacter) & 250 & $50: 1$ & 0.001 & ND & ND & ND & ND \\
\hline \multicolumn{8}{|l|}{ Chemogenic $\mathrm{Fe}(\mathrm{II})$} \\
\hline \multicolumn{8}{|l|}{ Phosphate } \\
\hline ChemoViv50 & 250 & $50: 1$ & 0.001 & ND & 2.02 & 0.34 & 0.99 \\
\hline
\end{tabular}




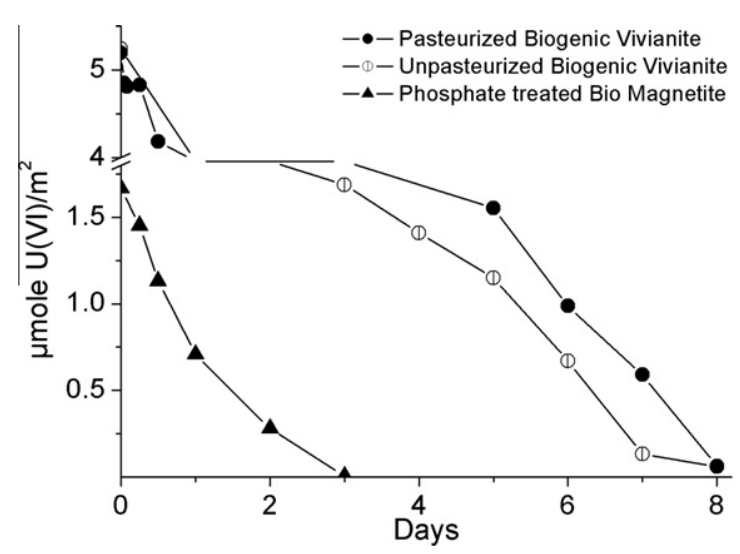

Fig. 6. Surface area normalized reduction of U(VI) by ( Pasteurized BioViv50 (S. putrefaciens), ( $\Phi)$ BioViv50 (S. putrefaciens) and (ム) BioMag50 + phosphate. All reductions performed in the presence of $1 \mathrm{mM}$ bicarbonate.

were considerably lower than for higher Fe:U ratios (Table 1), and reduction was initiated after a 3-day lag (Figure ure5). In experiments containing a 2:1 molar ratio of Fe:U, reduction did not take place (data not shown), suggesting insufficient reducing capacity to mediate the reduction.

Similarly, uranium adsorption onto vivianite (originating from $S$. putrefaciens or G. sulfurreducens) was very rapid (Fig. SC-1). The complete reduction of sorbed U(VI) occurred over a course of 8 days as evidenced by the decrease in sorbed $\mathrm{U}(\mathrm{VI})$ via conversion to $\mathrm{U}(\mathrm{IV}$ ) over time (Fig. 6 and SC-3). Uranium sorption and subsequent reduction was observed in both pasteurized and unpasteurized vivianite suspensions, suggesting a dominant abiotic redox process. Unlike biogenic magnetite, treatment of biogenic vivianite with $0.5 \mathrm{M}$ bicarbonate led to extraction of total uranium (data not shown). Hence all biogenic vivianite samples were treated with $0.1 \mathrm{M}$ bicarbonate which selectively removed U(VI) (confirmed by kinetic phosphorescence analysis).
Finally, magnetite to which phosphate was pre-sorbed at a surface coverage of $\sim 9 \mu \mathrm{mol} / \mathrm{m}^{2}$, also reduced $\mathrm{U}(\mathrm{VI})$ (Fig. 6) but the rate of reduction was intermediate between that of untreated magnetite and that of vivianite (Table 1). Similar to biogenic vivianite, extractions were carried out using $0.1 \mathrm{M}$ bicarbonate because treatment with $0.5 \mathrm{M}$ bicarbonate lead to extraction of total uranium (data not shown).

Consistent with our prior work (Sharp et al., 2009) ironfree batch cell suspensions of $S$. putrefaciens and $G$. sulfurreducens completely reduced $\mathrm{U}(\mathrm{VI})$ to $\mathrm{UO}_{2}$ in a matter of hours (Figs. SC-4).

\subsection{X-ray absorption spectroscopy (XAS)}

XANES analyses and linear combination fitting using $\mathrm{U}(\mathrm{VI})$ and U(IV) standards indicated the oxidation state of uranium to be tetravalent in magnetite samples with a $\mathrm{Fe}_{\text {total }}: \mathrm{U}$ ratio $>10: 1$ (Fig. SC-5). The pasteurized sample Mag10-Pas + Bicarb $\left(\mathrm{Fe}_{\text {total }}: \mathrm{U}\right.$ ratio 10:1) displayed a lag prior to uranium reduction, but eventually underwent near complete uranium reduction. This is consistent with lower Fe:U ratios having lower reduction capacities and leading to incomplete $(10: 1)$ or minimal $(2: 1) \mathrm{U}(\mathrm{VI})$ reduction. Uranium $\mathrm{L}_{\mathrm{III}}$-edge EXAFS was used to characterize the shortrange $(<4 \AA)$ and intermediate-range $(4-10 \AA)$ structure of the reduced uranium precipitates (Fig. 7). All spectra show general salient features expected for uraninite, most notably an U-O shell at $\sim 2.34 \AA$ (Table 2) and a U-U shell at $\sim 3.83 \AA$ (corresponding to the Fourier Transform (FT) peaks at 1.8 and $3.8 \AA, R+\delta R$ ). In addition to these features, FT peaks are present in the sample data for $\mathrm{R}>4 \AA$ (terminating at about $\AA$ ), indicating the presence of significant intermediate-range structural order (Schofield et al., 2008). A reduction in the expected coordination number $(\mathrm{CN})$ for the $\mathrm{U}-\mathrm{U}$ shell at $3.8 \AA$ was observed $(\mathrm{CN}=5.7-6.4$ atoms $)$ as compared to the bulk value of 12. A typical structurally ordered stoichiometric uraninite crystal structure has a $\mathrm{U}-\mathrm{U}$ coordination number $(\mathrm{CN})$ of 12 at approximately $3.8 \AA$. For small uraninite particles,

Table 2

Shell-by-shell EXAFS fits of all biogenic magnetite samples containing $\mathrm{UO}_{2}$ and biogenic $\mathrm{UO}_{2}$ produced by $S$. putrefaciens and $G$. sulfurreducens. Values within parenthesis indicate uncertainty. Values in parentheses are fit derived 1 sigma uncertainties in the last reported digit. All the samples above also included two additional U-U shells at distances fit to 6.66(3) and 7.84(6) $\AA$; coordination numbers fixed at 24 and 12 and the Debye-Waller factor fixed at 0.008 and 0.004 , respectively. These fixed values were derived from a model developed by Schofield et al. (2008) and allow the estimation of the ordered particle core diameter at about $1.5 \mathrm{~nm}$.

\begin{tabular}{|c|c|c|c|c|c|c|c|c|c|}
\hline \multirow[b]{2}{*}{ Samples } & \multicolumn{3}{|l|}{$\mathrm{U}-\mathrm{O}$} & \multicolumn{3}{|l|}{$\mathrm{U}-\mathrm{U}$} & \multicolumn{3}{|c|}{$\mathrm{U}-\mathrm{U}$} \\
\hline & $\mathrm{N}$ & $\mathrm{R}(\AA)$ & $\sigma^{2} \AA^{2}$ & $\mathrm{~N}$ & $\mathrm{R}(\AA)$ & $\sigma^{2} \AA^{2}$ & $\mathrm{~N}$ & $\mathrm{R}(\AA)$ & $\sigma^{2} \AA^{2}$ \\
\hline \multicolumn{10}{|l|}{ Unpasteurized } \\
\hline Mag100 + bicarb & $8(1)$ & $2.342(9)$ & $0.010(2)$ & $5(1)$ & $3.832(7)$ & $0.004(1)$ & 6 & $5.72(3)$ & 0.006 \\
\hline Mag100 & $7(1)$ & $2.34(1)$ & $0.009(2)$ & $6(1)$ & $3.835(7)$ & $0.004(1)$ & 6 & $5.75(3)$ & 0.006 \\
\hline Mag50 + bicarb & $6.4(9)$ & $2.335(8)$ & 0.007 (1) & $6(1)$ & $3.830(7)$ & $0.005(1)$ & 6 & $5.38(3)$ & 0.006 \\
\hline Mag20 + bicarb & $8(1)$ & $2.343(8)$ & $0.010(2)$ & $5.1(9)$ & $3.831(6)$ & $0.0033(8)$ & 6 & $5.73(3)$ & 0.006 \\
\hline $\mathrm{BioUO}_{2}$ & $8(1)$ & $2.339(8)$ & $0.011(1)$ & $4(1)$ & $3.833(7)$ & $0.005(1)$ & 6 & $5.46(2)$ & 0.006 \\
\hline \multicolumn{10}{|l|}{ Pasteurized } \\
\hline Mag10-Pas+bicarb & $7(1)$ & $2.337(9)$ & $0.009(1)$ & $6(1)$ & $3.829(6)$ & $0.0041(9)$ & 6 & $5.72(3)$ & 0.006 \\
\hline Mag50-Pas + bicarb & $7(1)$ & $2.338(8)$ & $0.009(2)$ & $5(1)$ & $3.831(6)$ & $0.0033(9)$ & 6 & $5.72(3)$ & 0.006 \\
\hline Mag50-Pas & $7(1)$ & $2.339(8)$ & $0.009(1)$ & $5.2(9)$ & $3.831(6)$ & $0.0034(9)$ & 6 & $5.72(3)$ & 0.006 \\
\hline
\end{tabular}


the number of $U$ atoms bound at the surface of the particle becomes comparable to the number of $U$ atoms within the interior of the particle, resulting in a decrease in the average U-U CN (4.1-6.1), which is consistent with EXAFS in the present study. This under-coordination is consistent with the nanoparticulate size and consequential high proportion of surface-exposed atoms (O'Loughlin et al., 2003; Schofield et al., 2008; Veeramani et al.; 2009; Sharp et al., 2009).

The same EXAFS results were observed for both unpasteurized and pasteurized magnetite samples, confirming that an abiotic process leads to uraninite formation. EXAFS analysis of the magnetite-containing samples in Fig. 7 -with the exception of the low $\mathrm{Fe}_{\text {total }}$ :U (2:1) sampleindicate the reduced uranium to be dominantly uraninite with intermediate range structure at $>4 \AA$. Similarly, systematic variation of the $\mathrm{Fe}: \mathrm{U}$ ratio did not affect the product as characterized by EXAFS (Fig. 7). Electron microscopy of the magnetite after uranium reduction also revealed the formation of uraninite as confirmed by selected area electron diffraction (SAED) (Fig. SC-6).

In contrast to the magnetite experiments, the product of $\mathrm{U}(\mathrm{VI})$ reduction by vivianite was a non-uraninite, monomeric uranium species. While XANES analysis confirmed complete reduction of uranium (Fig. SC-7), EXAFS did not display the U-U Fourier transform peak at $3.86 \AA$ typical of uraninite (Fig. 8). Had a U-U pair correlation been present in this sample, this peak would have appeared in the FT despite the shorter data range as compared to the magnetite samples. The absence of a U-U peak indicates the formation of a monomeric form of U(IV), which is likely to be a molecular species complexed by surface ligands. The formation of a precipitate is highly unlikely based on (1) the EXAFS spectra not showing the U-U Fourier transform peak at $3.86 \AA$ typical of uraninite and the EXAFS detection limit being around $10 \% \mathrm{UO}_{2}(2)$ complete desorption of U(IV) by a high concentration solution of bicarbonate (data not shown) and (3) no evidence of a precipitate by electron microscopy. We can thus conclude that the monomeric U(IV) mostly likely occurs as surface complexed species on vivianite surfaces.

Phosphate is a structural component of vivianite and shell-by-shell fits indicate the coordination of tetravalent uranium with two phosphorus shells at about $\sim 3.1 \AA$ and another P shell appears to be present at $\sim 3.8 \AA$ (Table 3). Attempts at fitting the data using $\mathrm{Fe}$ atoms (at 2.98 and $3.16 \AA$ ) did not converge (or converged on negative coordination numbers). Thus, U(IV) appears to be coordinated to phosphate rather than to $\mathrm{Fe}(\mathrm{II})$. A U(IV)-carbonate coordination was ruled out due to the absence of the characteristic multiple scattering feature of the distal oxygen atom (Hennig et al., 2010). Attempts at carrying out high-resolution electron microscopy and SAED on biogenic vivianite containing reduced uranium were unsuccessful since the uranium species was destroyed quickly when exposed to the electron beam (Fig. SC-6).

To investigate the role of phosphate in the formation of monomeric U(IV) species, uranium reduction was performed with biogenic magnetite that was pre-sorbed with phosphate. The rate of $\mathrm{U}(\mathrm{VI})$ reduction was slower for phosphate-treated magnetite when compared to untreated magnetite, presumably due to surface-associated phosphate blocking transfer of electrons from $\mathrm{Fe}(\mathrm{II})$ to U(VI). The phosphate-treated magnetite also produced monomeric U(IV) as evidenced by XAS analysis (Fig. 8). The product was almost identical to that obtained in the biogenic vivianite experiments: it lacked the typical spectral signature of uraninite and was best fit with one or two U-P shells at $\sim 3.1 \AA$ and $\sim 3.8 \AA$, respectively (Table 3 ).
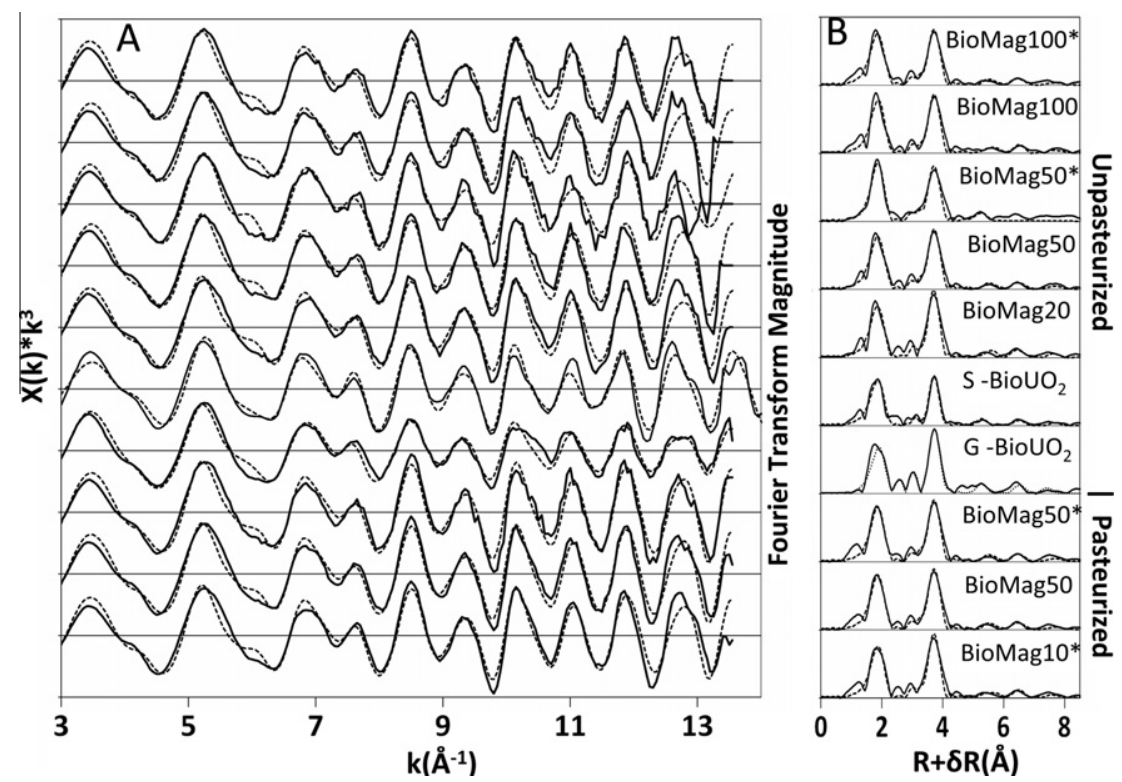

Fig. 7. (A) $\mathrm{U} \mathrm{L}_{\mathrm{III}}$ Edge EXAFS spectra for $\mathrm{UO}_{2}$ produced by pasteurized and unpasteurized magnetite samples, S. putrefaciens $\left(\mathrm{S}-\mathrm{BioUO} \mathrm{O}_{2}\right.$ ) and G. sulfurreducens $\left(\mathrm{G}-\mathrm{BioUO}_{2}\right)$ in absence of $\mathrm{Fe} \mathrm{B}$ ) Corresponding Fourier transforms. Data are indicated by solid lines and fits (shown in Table 2) by dashed lines. Samples marked with an asterisk indicate the presence of $1 \mathrm{mM}$ bicarbonate. The small FT peak at $\mathrm{R} \sim 1.5 \AA$ $(\mathrm{R}+\mathrm{dR})$ is known to result from the presence of a multi-electron excitation at $k=10.2 \AA^{-1}$ in all spectra. 

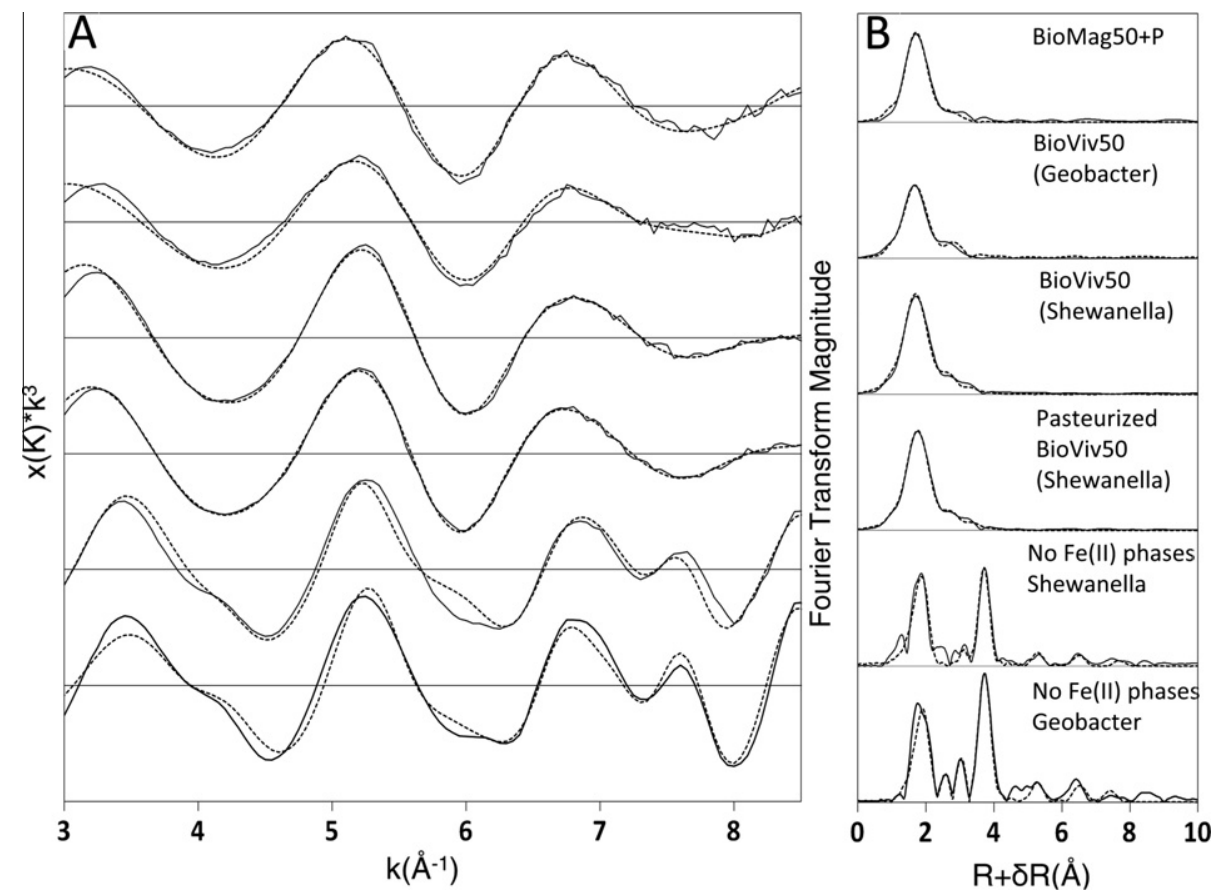

Fig. 8. (A) $\mathrm{U}_{\mathrm{III}}$ Edge EXAFS spectra for molecular U(IV) produced by pasteurized and unpasteurized bio-vivianite samples (derived from S. putrefaciens and G. sulfurreducens), phosphate treated bio-magnetite, $\mathrm{UO}_{2}$ produced by S. putrefaciens and G. sulfurreducens in absence of iron B) corresponding Fourier transforms. Data are indicated by solid lines and fits (shown in Table 3) by dashed lines. Fits for the bottom two spectra are available in Sharp et al. (2009).

Table 3

Shell-by-shell EXAFS fits of all biogenic vivianite samples and phosphate treated biogenic magnetite sample containing molecular U(IV). Values in parentheses are fit derived 1 sigma uncertainties in the last reported digit unless. Note the high coordination numbers for the U-O shell. An explanation of this occurrence is included in Supplementary Figs. SC-9.

\begin{tabular}{|c|c|c|c|c|c|c|c|c|c|}
\hline \multirow[b]{3}{*}{ Samples } & \multicolumn{9}{|c|}{ Molecular U(IV) produced by biogenic vivianite and phosphate treated biogenic magnetite } \\
\hline & \multicolumn{3}{|l|}{$\mathrm{U}-\mathrm{O}$} & \multicolumn{3}{|l|}{$\mathrm{U}-\mathrm{P} 1$} & \multicolumn{3}{|l|}{$\mathrm{U}-\mathrm{P} 2$} \\
\hline & $N$ & $R(\AA)$ & $\begin{array}{l}\sigma^{2} \times 10^{-3} \\
\left(\AA^{2}\right)\end{array}$ & $N$ & $R(\AA)$ & $\begin{array}{l}\sigma^{2} \times 10^{-3} \\
\left(\AA^{2}\right)\end{array}$ & $N$ & $R(\AA)$ & $\begin{array}{l}\sigma^{2} \times 10^{-3} \\
\left(\AA^{2}\right)\end{array}$ \\
\hline BioViv50 (S. putrefaciens) & $11(1)$ & $2.351(6)$ & 0.015 & $2.4(2)$ & $3.170(8)$ & 0.01 & $2.2(7)$ & $3.775(9)$ & 0.01 \\
\hline $\begin{array}{l}\text { Pasteurized BioViv50 ( } S \text {. } \\
\text { putrefaciens) }\end{array}$ & $13(2)$ & $2.396(9)$ & $0.018(1)$ & $2.6(4)$ & $3.139(6)$ & 0.01 & $2.1(4)$ & $3.896(1)$ & 0.01 \\
\hline BioViv50 (G. sulfurreducens) & $7(1)$ & $2.370(2)$ & $0.010(2)$ & $2.0(5)$ & $3.052(8)$ & 0.01 & & & \\
\hline BioMag $50+$ phosphate & $8(2)$ & $2.330(2)$ & $0.014(2)$ & $2.0(5)$ & $3.11(7)$ & 0.01 & & & \\
\hline
\end{tabular}

Transmission electron microscopy (dark-field STEM) of a biogenic magnetite sample with sorbed phosphate detected the presence of vivianite by SAED (Fig. SC-8). However, there was no evidence of a vivianite coating on the magnetite particles (Fig. SC-8). It appears as though separate vivianite particles were formed upon addition of phosphate to magnetite. A detailed analysis of the elemental distribution in this sample (Fig. 9) revealed a relatively uniform distribution of $\mathrm{P}$, suggesting the sorption of phosphate on the surface of magnetite in addition to the formation of distinct vivianite particles. The elemental distribution of $U$ only partially overlaps with that of $\mathrm{P}$ pointing to the formation of species that include $\mathrm{U}$ and $\mathrm{P}$ as well as that of phosphate-free uranium clusters. The imperfect overlap of $\mathrm{U}$ and $\mathrm{P}$ may be attributed to the relatively low $\mathrm{P}$ and $\mathrm{U}$ concentrations and to the coarseness of the pixel size used for the images. Attempts to perform selected area electron diffraction (SAED) on the uranium phase were unsuccessful due to beam damage.

\section{DISCUSSION}

Magnetite and vivianite formation by $S$. putrefaciens $\mathrm{CN} 32$ has been reported by several researchers (Bell et al., 1987; Kostka and Luther, 1995; Roden and Zachara, 1996; Fredrickson et al., 1998; Dong et al., 2000; O'Loughlin et al., 2007).

Mössbauer analysis of biogenic magnetite at $245 \mathrm{~K}$ particularly the small hyperfine field - suggests the presence of fine-grained or nanoparticulate magnetite (Goya et al., 


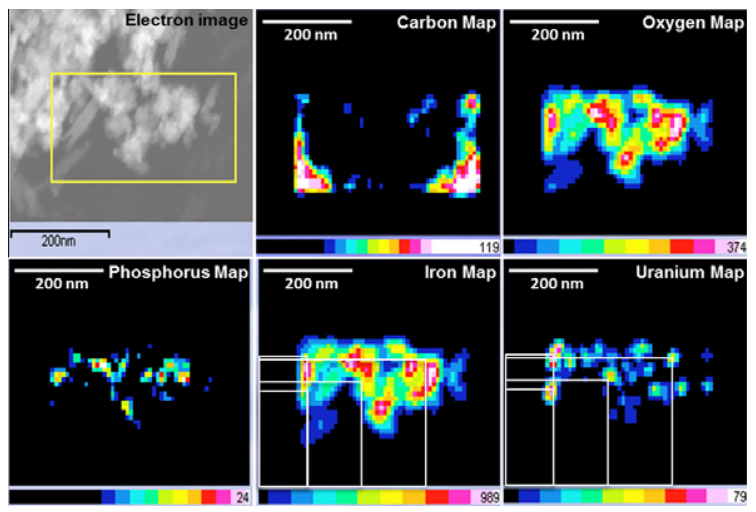

Fig. 9. EDS mapping of sample of phosphate-reacted magnetite incubated with $\mathrm{U}(\mathrm{VI})$.

2003; Corr et al., 2004) and/or phases with low crystallinity. Similar results have been reported by Van der Zee et al. (2003) and Thompson et al. (2006) and for soil and sediment samples, and have been attributed to nano-goethite phases. This could also include some transition state between HFO and magnetite. However, 'pure' 2-line ferrihydrite can be excluded as it does not display any hyperfine field at $245 \mathrm{~K}$. While the possibility of the broadened signal containing more than one overlapping spectrum cannot be excluded, the data are consistent with the presence of nanoparticulate goethite and magnetite. Electron microscopy confirmed traces of goethite coexisting with magnetite. A possible explanation for the presence of goethite is the slow crystallization of HFO to goethite during the 12-day course of the experiment (Cornell et al., 1989). We thus suggest that goethite was present in small quantities and was perhaps less bioavailable for reduction to magnetite.

Mössbauer analysis also pointed to the presence of siderite as a minor species (ca. 10\%). The presence of bicarbonate $(30 \mathrm{mM})$ during microbial HFO reduction could have led to formation of siderite. Alternatively, traces of goethite may have been reduced to siderite as previously reported by Liu et al. (2001). However, neither electron microscopy nor X-ray power diffraction indicated the presence of siderite.

The complexity of the biogenic minerals produced by $S$. putrefaciens is reminiscent of the findings of PerezGonzalez et al. (2010) for biogenic magnetite produced by $S$. oneidensis. They attribute this complexity to the incorporation of organics within the magnetite structure, which makes spectroscopic analysis challenging. While organics could remain associated with the biogenic magnetite, it is reasonable to postulate that they play little or no role in $\mathrm{U}(\mathrm{VI})$ reduction since other biogenic mineral phases that we produced did not catalyze any reduction (data not shown). The association of siderite and goethite with biogenic magnetite results in a relatively complex counterpart to chemically synthesized magnetite.

Mössbauer analysis of biogenic vivianite samples at 245 and $77 \mathrm{~K}$ indicated the presence of vivianite and traces of phosphoferrite. This is consistent with the electron microscopy results that also indicate co-existence of the two phases. The incomplete splitting of the doublet at $5 \mathrm{~K}$ suggests nano-particulate vivianite, but electron microscopy indicated vivianite particles in the sub-micron to micron range. The presence of trace phosphoferrite could be due to the transformation of vivianite to phosphoferrite upon drying (Mattievich and Danon, 1977).

Uranium reduction by magnetite has been extensively studied. However, the rate of uranium reduction and the end speciation of uranium are often variable. In this work, we report complete U(VI) reduction over 4-9 days, depending on the Fe: $U$ ratio. Uranium reduction is first-order with respect to the uranium (Fig. SC-2) and the rates of reduction by biogenic magnetite vary from that reported previously for chemogenic or synthetic magnetite. This observed difference in U(VI) reduction rates between biogenic and synthetic magnetites is likely due to higher specific surface area and corresponding increased reactivity of biogenic magnetite (ca. $54 \mathrm{~m}^{2} / \mathrm{g}$ ) than those reported for synthetic magnetite in the literature. For instance, Missana et al. (2003), Regenspurg et al. (2009) and Ilton et al. (2010) reported SSA for synthetic magnetite of 19.7, 8.5 and $13.5 \mathrm{~m}^{2} / \mathrm{g}$, respectively and corresponding reduction time of 27, 90 and 35 days for complete to near-complete reduction, respectively. Similarly, Aamrani et al. (2007), Rovira et al. (2007) and Duro et al. (2008) and reported a SSA for commercial magnetite of about $1.6 \mathrm{~m}^{2} / \mathrm{g}$ and corresponding reduction time of 25,85 and 60 days for complete to near-complete reduction, respectively. The stoichiometry of magnetite is also likely to play in role in modulating the rates of $\mathrm{U}(\mathrm{VI})$ reduction. This has been demonstrated for aromatic $\mathrm{NO}_{2}$ reduction, for instance (Gorski et al., 2010).

The composition of the aqueous matrix used in our uranium reduction experiments differs considerably from those reported in other studies. For example, Regenspurg et al. (2009) reported enhanced uranium reduction in the presence of $1 \mathrm{mM}$ bicarbonate. In our work, the presence or absence of bicarbonate $(1 \mathrm{mM})$ does not greatly affect the rates of uranium reduction. Finally, rates of uranium reduction (and a short lag time) increase linearly with increasing magnetite concentrations or Fe: $\mathrm{U}$ ratios (10:1-50:1), which is indicative of a first-order reaction with respect to iron (Table 1).

The reduction of $\mathrm{U}(\mathrm{VI})-\mathrm{U}(\mathrm{IV})$ occurred in all biogenic magnetite systems, with increasing lag times and amounts of U(VI) remaining in systems containing smaller amounts of biogenic magnetite (low Fe: $\mathrm{U}$ ratio). The slower rates and lag time are likely due to differences in the sorption density of U(VI) on the Fe(II) minerals. A higher U(VI) sorption density may lower the reducing capacity. Similar results have been reported by Boyanov et al. (2009).

Reduction of uranium by biogenic vivianite was also first-order with respect to uranium (Fig. SC-3). Reduction was shown to occur in pasteurized and unpasteurized suspensions indicating that pasteurization does not affect the properties of the biogenic mineral and that reduction is an abiotic process. To our knowledge, this is the first report demonstrating uranium reduction by biogenic vivianite. Attempts to perform uranium reduction with chemogenic vivianite revealed instantaneous adsorption of uranium but no reduction (data not shown). Electron microscopy 
revealed chemogenic vivianite to be larger than biogenic vivianite (data not shown). No impurities in the chemogenic vivianite were detected using electron microscopy. This is suggestive of differences in specific surface area between biogenic and chemogenic vivianite which in turn could affect their ability to reduce uranium.

XAS revealed that, in the absence of added phosphate, uranium reduced by biogenic magnetite forms crystalline $\mathrm{UO}_{2}$. Coupled with XANES analyses that suggest dominance of $\mathrm{U}(\mathrm{IV})$, an absence of distortion in the $\mathrm{U}-\mathrm{O}$ shell is also suggestive of stoichiometric $\mathrm{UO}_{2.00}$, unlike nonstoichiometric $\mathrm{UO}_{2+\mathrm{X}}$ which exhibits a split $\mathrm{U}-\mathrm{O}$ shell (Conradson et al., 2004; Bargar et al., 2008; Schofield et al., 2008). We thus conclude that uranium reduction in the biogenic magnetite system leads to the formation of structurally ordered crystalline uraninite with a composition close to $\mathrm{UO}_{2.00}$.

Similarly, biogenic $\mathrm{UO}_{2}$ was produced via the enzymatic reduction of $\mathrm{U}(\mathrm{VI})$ by $S$. putrefaciens and $G$. sulfurreducens in the absence of $\mathrm{Fe}$ (III) and shows the same salient features as that of nanoparticulate $\mathrm{UO}_{2}$ produced by biogenic magnetite in this study and reported elsewhere (Schofield et al., 2008; Bargar et al., 2008; Sharp et al., 2009; Veeramani et al., 2009).

In contrast to biogenic magnetite, $\mathrm{U}(\mathrm{VI})$ reduction by biogenic vivianite (from $S$. putrefaciens) leads to the formation of a sorbed monomeric U(IV) species as indicated by EXAFS analysis.

The experiments involving biogenic vivianite were carried out also in the presence of $1 \mathrm{mM}$ bicarbonate. Hennig et al. (2010) recently illustrated the importance of U(IV) carbonate complexes that exhibit a carbonate coordination resulting in a characteristic multiple scattering feature of the distal oxygen atom. The absence of this feature in the present study seems to indicate a minor importance of carbonate coordination.

Vivianite has been shown to reductively immobilize other heavy metals such as cobalt and strontium in the environment (Zachara et al., 2001; Roden et al., 2002). The present work clearly indicates its role in uranium reduction. To confirm this finding, uranium was reduced by biogenic vivianite that was produced by a phylogenetically different bacterium, G. sulfurreducens. XAS analysis of that sample gave results that were remarkably similar to that of the biogenic vivianite produced by $S$. putrefaciens $\mathrm{CN} 32$, demonstrating the ability of biogenic vivianite originating from varied microbial phylogeny to reduce $U(V I)$ and favor the formation of monomeric U(IV) species. Interestingly, in the absence of iron phases, enzymatic uranium reduction by cultures of $S$. putrefaciens and $G$. sulfurreducens lead to the formation of crystalline uraninite (Sharp et al., 2009). This strongly suggests an impediment to uraninite formation where abiotic uranium reduction is driven by a phosphate-bearing $\mathrm{Fe}(\mathrm{II})$ phase.

The role of phosphate in the speciation of hexavalent uranium is well studied (Markich, 2002). However its role in the speciation of reduced uranium in environmentally relevant systems is less well known. In this work, we indicate that the presence of orthophosphate clearly affects the speciation of reduced uranium. While magnetite was shown to produce uraninite, magnetite from the same batch, when pre-treated with phosphate, was shown to reduce uranium to monomeric U(IV). The EXAFS results were strikingly similar to that for the biogenic vivianites tested, suggesting a common mechanism of inhibition of uraninite formation by structural and sorbed phosphate. XAS fit results point toward coordination of U(IV) with phosphorus, which is consistent with the role of phosphate in binding U(IV) and preventing uraninite nucleation.

The apparent sorption of phosphate at circumneutral $\mathrm{pH}$ on biogenic magnetite was considerably higher than that reported by Daou et al. (2007), which is consistent with the formation of a separate phase, vivianite. Detailed electron microscopy analysis of the phosphate-reacted magnetite sample incubated with $\mathrm{U}(\mathrm{VI})$ led to the conclusion that U-P species was formed. However, it is notable that in the presence of phosphate (see $\mathrm{P}, \mathrm{U}$ and $\mathrm{Fe}$ maps in Fig. 9), $\mathrm{UO}_{2}$ does not dominate the sample (see Fig. 8) contrary to the product found in the phosphate-free magnetite samples. This finding highlights the potential role of phosphate in modulating the formation of uraninite in the subsurface independently from the presence of uraniniteproducing $\mathrm{Fe}(\mathrm{II})$-bearing phases such as magnetite.

The formation of monomeric U(IV) as a product of biogenic-Fe(II) mediated abiotic U(VI) reduction contributes to a growing body of evidence for the formation of nonuraninite forms of reduced uranium during in situ immobilization. Kelly et al. (2008) reported reduction of uranium in microcosm experiments in which uranium was reduced to $\mathrm{U}(\mathrm{IV})$ that remained adsorbed to $\mathrm{Fe} / \mathrm{Mn}$ minerals. Recent findings by Boyanov et al. (2009) suggest yet another form of monomeric U(IV), which the authors dub monomeric U(IV)- $\mathrm{O}_{8}$ hexahedra that was found to be associated with $\mathrm{Fe}(\mathrm{III}) / \mathrm{Fe}(\mathrm{II})$ minerals. Another recent study by Kelly et al. (2010) investigating uranium reduction in microcosm experiments reported the end product of uranium reduction to be a mixture of uraninite and monomeric U(IV) associated with $\mathrm{Fe}$ surfaces. Finally, batch uranium reduction experiments with Gram positive, spore-forming bacteria Desulfotomaculum reducens MI-1 and Clostridium acetobutylicum as well as the Gram negative bacterium $S$. oneidensis MR-1 carrying the reduction in a similar medium as the Gram positive bacteria resulted in the formation of monomeric U(IV) (Bernier-Latmani et al., 2010). Likewise, Fletcher et al. (2010) reported formation of mononuclear U(IV) by Desulfitobacterium spp.

\section{CONCLUSIONS AND ENVIRONMENTAL IMPLICATIONS}

Under reducing conditions in the environment, uranium reduction will often occur in the presence of biologically reduced iron-bearing minerals. Although bacteria can enzymatically reduce uranium, abiotic processes leading to uranium reduction in the environment are also likely to be important. While studies have considered uraninite to be the primary product of uranium reduction (Langmuir 1978), evidence from this and other (Fletcher et al., 2010; Bernier-Latmani et al., 2010) work strongly suggests the formation of non-uraninite species of reduced uranium 
including monomeric U(IV) species. Importantly, the presence of structural or sorbed phosphate inhibits uraninite formation. While the precise mechanism of this inhibition is unknown, it appears that monomeric U(IV) is associated with the phosphate groups that are either adsorbed and/or structurally bound to $\mathrm{Fe}(\mathrm{II})$-bearing minerals.

While the reactivity of biogenic uraninite has been studied and documented (Ulrich et al., 2008; Ulrich et al., 2009), the reactivity and stability of monomeric U(IV) in the environment is unknown. The results presented in this paper suggest that there is a wealth of U(IV) chemistry not fully understood in these systems, and that there may be complex mixtures of U(IV) products in the field. For accurate predictions of the stability of reduced $U$ in the subsurface, it will be critical to consider the stability of these species in future hydrogeochemical models. A thorough understanding of the structure, composition, occurrence, and stability of these species is crucial to assess the feasibility of in situ reductive bioremediation.

\section{ACKNOWLEDGEMENTS}

We thank Dorothy Parker, Anca Haiduc, Dan Giammar and Brad Tebo for helpful discussion and feedback in preparing this manuscript. Funding for this project was provided by a DOEOBER Grant to S.L.A.C. (work package number 2009-SLAC10006), and Grant No. DE-FG02-06ER64227 to E.P.F.L. and Swiss NSF Grants No. 20021-113784 and No. 200020-126821/1. Portions of this research were carried out at the Stanford Synchrotron Radiation Lightsource, a national user facility operated by Stanford University on behalf of the US DOE, Office of Basic Energy Sciences. D.S.A. was partially funded by a Marie Curie International Incoming Fellowship (FP7-PEOPLE-2009-IIF-254143) from the European Commission. We also thank CIME (Interdisciplinary Centre for Electron Microscopy) at EPFL for use of the electron microscope facility, Chris Fuller (USGS) for providing adsorbed U(IV) standards and Takuya Echigo (Virginia Tech) for providing XRD reference spectra.

\section{APPENDIX A. SUPPLEMENTARY DATA}

Supplementary data associated with this article can be found, in the online version, at doi:10.1016/j.gca.2011.02. 024.

\section{REFERENCES}

Aamrani S. E., Giménez J., Rovira M., Seco F., Grivé M., Bruno J., Duro L. and De Pablo J. (2007) A spectroscopic study of uranium(VI) interaction with magnetite. Appl. Surf. Sci. 253, 8794-8797.

Abdelouas A., Lu Y., Lutze W. and Nuttall H. E. (1998) Reduction of $\mathrm{U}(\mathrm{VI})$ to $\mathrm{U}(\mathrm{IV})$ by indigenous bacteria in contaminated ground water. J. Contam. Hydrol. 35, 217-233.

Al-Borno A. and Tomson M. B. (1994) The temperature dependence of the solubility product constant of vivianite. Geochim. Cosmochim. Acta 58, 5373-5378.

Anderson R., Vrionis H., Ortiz-Bernad I., Resch C., Long P., Dayvault R., Karp K., Marutzky S., Metzler D., Peacock A., White D., Lowe M., and Lovley D. (2003). Stimulating the in situ activity of geobacter species to remove uranium from the groundwater of a uranium-contaminated aquifer. Appl. Environ. Microbiol. 5884-5891.

Bargar J. R., Bernier-Latmani R., Giammar D. E. and Tebo B. M. (2008) Biogenic uraninite nanoparticles and their importance for uranium remediation. Elements 4, 407-412.

Behrends T. and Van Cappellen P. (2005) Competition between enzymatic and abiotic reduction of uranium(VI) under iron reducing conditions. Chem. Geol. 220, 315-327.

Bell P. E., Mills A. L. and Herman J. S. (1987) Biogeochemical conditions favoring magnetite formation during anaerobic iron reduction. Appl. Environ. Microbiol. 53, 2610-2616.

Bernier-Latmani R., Veeramani H., Della Vecchia E., Junier P., Lezama-Pacheco J. S., Suvorova E. I., Sharp J. O., Wigginton N. S. and Bargar J. R. (2010) Non-uraninite products of microbial. Environ. Sci. Technol. 44, 9456-9462.

Boyanov M., Latta D., O'loughlin E., Gorski C., Scherer M., and Kemner K. (2009) Distinct uranium(IV) products result from uranyl reduction in different ferrous-ferric oxyhydroxide systems. Geochim. Cosmochim. Acta A151-A151.

Boyanov M., O'Loughlin E., Roden E., Fein J., and Kemner K. (2007) Adsorption of Fe(II) and U(VI) to carboxyl-functionalized microspheres: The influence of speciation on uranyl reduction studied by titration and XAFS. Geochim. Cosmochim. Acta 1898-1912.

Bruggeman C. and Maes N. (2010) Uptake of uranium(VI) by pyrite under boom clay conditions: influence of dissolved organic carbon. Environ. Sci. Technol. 44, 4210-4216.

Buffle J., De Vitre R. R., Perret D. and Leppard G. G. (1989) Physico-chemical characteristics of a colloidal iron phosphate species formed at the oxic-anoxic interface of a eutrophic lake. Geochim. Cosmochim. Acta 53, 399-408.

Chakraborty S., Boivin F., Banerjee D., Scheinost A., Mullet M., Jacques Ehrhardt Jea, Brendle J., Vidal L. and Charlet L. (2010) U(VI) Sorption and reduction by Fe(II) sorbed on montmorillonite. Environ. Sci. Technol. 44, 3779-3785.

Charlet L., Liger E. and Gerasimo P. (1998) Decontamination of TCE- and U-rich waters by granular iron: role of sorbed $\mathrm{Fe}(\mathrm{II})$. J. Environ. Eng. 124, 25-30.

Chaudhuri S. K., Lack J. G. and Coates J. D. (2001) Biogenic magnetite formation through anaerobic biooxidation of $\mathrm{Fe}(\mathrm{II})$. Appl. Environ. Microbiol. 67, 2844-2848.

Conradson S. D., Manara D., Wastin F., Clark D. L., Lander G. H., Morales L. A., Rebizant J. and Rondinella V. V. (2004) Local structure and charge distribution in the UO2-U4O9 system. Inorg. Chem. 43, 6922-6935.

Cornell R., Giovanoli R., and Schneider W. (1989) Review of the hydrolysis of iron(III) and the crystallization of amorphous iron(III) hydroxide hydrate. J. Chem. Technol. Biotechnol. 115134.

Corr S. A., Gun'ko Y. K., Douvalis A. P., Venkatesan M. and Gunning R. D. (2004) Magnetite nanocrystals from a single source metallorganic precursor: metallorganic chemistry vs biogeneric bacteria. J. Mater. Chem. 14, 944-946.

Daou T. J., Begin-Colin S., Grenèche J. M., Thomas F., Derory A., Bernhardt P., Legaré P. and Pourroy G. (2007) Phosphate adsorption properties of magnetite-based nanoparticles. Chem. Mater. 19, 4494-4505.

Dodge C. J., Francis A. J., Gillow J. B., Halada G. P., Eng C. and Clayton C. R. (2002) Association of uranium with iron oxides typically formed on corroding steel surfaces. Environ. Sci. Technol. 36, 3504-3511.

Dong H., Fredrickson J. K., Kennedy D. W., Zachara J. M., Kukkadapu R. K. and Onstott T. C. (2000) Mineral transformations associated with the microbial reduction of magnetite. Chem. Geol. 169, 299-318. 
Duro L., El Aamrani S., Rovira M., De Pablo J. and Bruno J. (2008) Study of the interaction between $\mathrm{U}(\mathrm{VI})$ and the anoxic corrosion products of carbon steel. Appl. Geochem. 23, 1094-1100.

Elias D., Krumholz L., Wong D., Long P., and Suflita J. (2003) Characterization of microbial activities and $U$ reduction in a shallow aquifer contaminated by uranium mill tailings. Microb. Ecol. 83-91.

Elias D., Suflita J., Mcinerney M., and Krumholz L. (2004) Periplasmic cytochrome $\mathrm{C}_{3}$ of Desulfovibrio vulgaris is directly involved in $\mathrm{H}_{2}$-mediated metal but not sulfate reduction. Appl. Environ. Microbiol. 413-420.

Finneran K., Housewright M., and Lovley D. (2002) Multiple influences of nitrate on uranium solubility during bioremediation of uranium-contaminated subsurface sediments. Environ. Microbiol. 510-516.

Fletcher K. E., Boyanov M. I., Thomas S. H., Wu Q., Kemner K. M. and Loffler F. E. (2010) U(VI) reduction to mononuclear U(IV) by Desulfitobacterium species. Environ. Sci. Technol. 44, 4705-4709.

Forsyth, J.B., Johnson, C.E., and Wilkinsons C. (1970) The magnetic structure of vivianite, $\mathrm{Fe}_{3}\left(\mathrm{PO}_{4}\right)_{2} .8 \mathrm{H}_{2} \mathrm{O}$. J. Phys. C: Solid State Phys. 3, 1127.

Fredrickson J., Zachara J., Kennedy D., Duff M., Gorby Y., Li S., and Krupka K. (2000) Reduction of U(VI) in goethite (alpha$\mathrm{FeOOH}$ ) suspensions by a dissimilatory metal-reducing bacterium. Geochim. Cosmochim. Acta 3085-3098.

Fredrickson J. K., Zachara J. M., Kennedy D. W., Dong H., Onstott T. C., Hinman N. W. and Li S.-M. (1998) Biogenic iron mineralization accompanying the dissimilatory reduction of hydrous ferric oxide by a groundwater bacterium. Geochim. Cosmochim. Acta 62, 3239-3257.

Galloway W. E. (1978) Uranium mineralization in a coastal-plain fluvial aquifer system; catahoula formation. Texas. Econ. Geol. 73, 1655-1676.

Gorski C. A. and Scherer M. M. (2010) Determination of nanoparticulate magnetite stoichiometry by Mössbauer spectroscopy, acidic dissolution, and powder X-ray diffraction: a critical review. Am. Mineral. 95, 1017-1026.

Gorski C., Nurmi J., Tratnyek P., Hofstetter T. and Scherer M. (2010) Redox behavior of magnetite: implications for contaminant reduction. Environ. Sci. Technol. 44, 55-60.

Goya G. F., Berquo T. S., Fonseca F. C. and Morales M. P. (2003) Static and dynamic magnetic properties of spherical magnetite nanoparticles. J. Appl. Phys. 94, 3520-3528.

Hennig C., Ikeda-Ohno A., Emmerling F., Kraus W. and Bernhard G. (2010) Comparitive investigation of the solution species

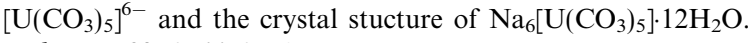
Dalton T. 39, 3744-3750.

Ilton E. S., Boily J.-F. O., Buck E. C., Skomurski F. N., Rosso K. M., Cahill C. L., Bargar J. R. and Felmy A. R. (2010) Influence of dynamical conditions on the reduction of $\mathrm{U}(\mathrm{VI})$ at the magnetite solution interface. Environ. Sci. Technol. 44, 170-176.

Ilton E. S., Haiduc A., Moses C. O., Heald S. M., Elbert D. C. and Veblen D. R. (2004) Heterogeneous reduction of uranyl by micas: crystal chemical and solution controls. Geochim. Cosmochim. Acta 68, 2417-2435.

Ilton ES A., Haiduc A., Cahill C. L. and Felmy A. R. (2005) Mica surfaces stabilize pentavalent uranium. Inorg. Chem. 44, 29862988.

Ilton E. S., Heald S. M., Smith S. C., Elbert D. and Liu C. (2006) Reduction of uranyl in the interlayer region of low iron micas under anoxic and aerobic conditions. Environ. Sci. Technol. 40, 5003-5009.

Ishikawa T., Kondo Y., Yasukawa A., and Kandori K. (1998) Formation of magnetite in the presence of ferric oxyhydroxides. Corros. Sci. 1239-1251.
Jeon B.-H., Dempsey B. A., Burgos W. D., Barnett M. O. and Roden E. E. (2005) Chemical reduction of U(VI) by Fe(II) at the solid-water interface using natural and synthetic Fe(III) oxides. Environ. Sci. Technol. 39, 5642-5649.

Jeon B.-H., Kelly S. D., Kemner K. M., Barnett M. O., Burgos W. D., Dempsey B. A. and Roden E. E. (2004) Microbial reduction of U(VI) at the solid-water interface. Environ. Sci. Technol. 38, 5649-5655.

Kappler A. and Straub K. L. (2005) Geomicrobiological cycling of iron. Rev. Mineral. Geochem. 59, 85-108.

Kelly S., Wu W., Yang F., Criddle C., Marsh T., O’loughlin E., Ravel B., Watson D., Jardine P., and Kemner K. (2010) Uranium transformations in static microcosms. Environ. Sci. Technol. 236-242.

Kelly S. D., Kemner K. M., Carley J., Criddle C., Jardine P. M., Marsh T. L., Phillips D., Watson D. and Wu W.-M. (2008) Speciation of uranium in sediments before and after in situ biostimulation. Environ. Sci. Technol. 42, 1558-1564.

Komlos J., Peacock A., Kukkadapu R. K. and Jaffé P. R. (2008) Long-term dynamics of uranium reduction/reoxidation under low sulfate conditions. Geochim. Cosmochim. Acta 72, 36033615.

Konhauser K. O. (1998) Diversity of bacterial iron mineralization. Earth Sci. Rev. 43, 91-121.

Kostka J., Dalton D., Skelton H., Dollhopf S. and Stucki J. (2002) Growth of iron(III)-reducing bacteria on clay minerals as the sole electron acceptor and comparison of growth yields on a variety of oxidized iron forms. Appl. Environ. Microbiol. 68, 6256-6262.

Kostka J. E. and Luther G. W. (1995) Seasonal cycling of Fe in saltmarsh sediments. Biogeochemistry 29, 159-181.

Langmuir D. (1978) Uranium solution-mineral equilibria at low temperatures with applications to sedimentary ore deposits. Geochim. Cosmochim. Acta 42, 547-569.

Liger E., Charlet L. and Van Cappellen P. (1999) Surface catalysis of uranium(VI) reduction by iron(II). Geochim. Cosmochim. Acta 63, 2939-2955.

Liu C., Kota S., Zachara J. M., Fredrickson J. K. and Brinkman C. K. (2001) Kinetic analysis of the bacterial reduction of goethite. Environ. Sci. Technol. 35, 2482-2490.

Lovley D. (1993) Dissimilatory metal reduction. Annu. Rev. Microbiol. 263-290.

Lovley D. R., Stolz J. F., Nord G. L. and Phillips E. J. P. (1987) Anaerobic production of magnetite by a dissimilatory ironreducing microorganism. Nature 330, 252-254.

Manning P. G., Murphy T. P. and Prepas E. E. (1991) Intensive formation of vivianite in the bottom sediments of mesotrophic narrow lake. Alberta. Can. Mineral. 29, 77-85.

Markich S. J. (2002) Uranium speciation and bioavailability in aquatic systems: an overview. Sci. World J. 2, 707-729.

Mattievich E. and Danon J. (1977) Hydrothermal synthesis and Mössbauer studies of ferrous phosphates of the homologous series $\mathrm{Fe}_{3}{ }^{2+}\left(\mathrm{PO}_{4}\right)_{2}\left(\mathrm{H}_{2} \mathrm{O}\right)_{n}$. J. Inorg. Nucl. Chem. 39, 569-580.

Mccammon C. A. and Burns R. G. (1980) The oxidation mechanism of vivianite as studies by Mössbauer spectroscopy. Am. Mineral. 65, 361-366.

Missana T., García-Gutiérrez M. and Fernndez V. (2003) Uranium (VI) sorption on colloidal magnetite under anoxic environment: experimental study and surface complexation modelling. Geochim. Cosmochim. Acta 67, 2543-2550.

Moskowitz B. M., Frankel R. B., Bazylinski D. A., Jannasch H. W. and Lovley D. R. (1989) A comparison of magnetite particles produced anaerobically by magnetotactic and dissimilatory iron-reducing bacteria. Geophys. Res. Lett. 16, 665-668.

N'Guessan A. L., Vrionis H. A., Resch C. T., Long P. E. and Lovley D. R. (2008) Sustained removal of uranium from 
contaminated groundwater following stimulation of dissimilatory metal reduction. Environ. Sci. Technol. 42, 2999-3004.

Nriagu J. O. (1972) Stability of vivianite and ion-pair formation in the system $\mathrm{Fe}_{3}\left(\mathrm{PO}_{4}\right) 2-\mathrm{H}_{3} \mathrm{PO}_{4} \mathrm{H}_{3} \mathrm{PO}_{0}-\mathrm{H}_{2} \mathrm{O}$. Geochim. Cosmochim. Acta 36, 459-470.

Nriagu J. O. and Dell C. J. (1974) Diagenetic formation of iron phosphates in recent lake sediments. Am. Mineral. 59, 934-946.

O'Loughlin E., Kelly S., Cook R., Csencsits R., and Kemner K. (2003) Reduction of uranium(VI) by mixed iron(II)/iron(II) hydroxide (green rust): Formation of $\mathrm{UO}_{2}$ manoparticies. Environ. Sci. Technol. 721-727.

O'Loughlin E., Larese-Casanova P., Scherer M. and Cook R. (2007) Green rust formation from the bioreduction of gamma$\mathrm{FeOOH}$ (lepidocrocite): comparison of several Shewanella species. Geomicrobiol. J., 211-230.

O'Loughlin E. J., Kelly S. D. and Kemner K. M. (2010) XAFS investigation of the interactions of $\mathrm{U}^{\mathrm{VI}}$ with secondary mineralization products from the bioreduction of $\mathrm{Fe}^{\mathrm{III}}$ oxides. Environ. Sci. Technol. 44, 1656-1661.

Palmisano A. and Hazen T. (2003) Bioremediation of metals and radionuclides: What it is and how it works (2nd ed.) $P B D: 30$ Sep 2003.

Peretyazhko T. S., Zachara J. M., Kennedy D. W., Fredrickson J. K., Arey B. W., McKinley J. P., Wang C. M., Dohnalkova A. C. and Xia Y. (2010) Ferrous phosphate surface precipitates resulting from the reduction of intragrain 6-line ferrihydrite by Shewanella oneidensis MR-1. Geochim. Cosmochim. Acta 74, 3751-3767.

Perez-Gonzalez T., Jimenez-Lopez C., Neal A. L., Rull-Perez F., Rodriguez-Navarro A., Fernandez-Vivas A. and Iañez-Pareja E. (2010) Magnetite biomineralization induced by Shewanella oneidensis. Geochim. Cosmochim. Acta 74, 967-979.

Posey-Dowty J., Axtmann E., Crerar D. A., Borcsik M. P., Ronk A. and Woods W. (1987) Dissolution rate of uraninite and uranium roll-front ores. Econ. Geol. 82, 184-194.

Ravel B. and Newville M. (2005) ATHENA, ARTEMIS, HEPHAESTUS: data analysis for X-ray absorption spectroscopy using IFEFFIT. J. Synchrotron Radiat. 12, 537-541.

Regenspurg S., Schild D., Schäfer T., Huber F. and Malmström M. E. (2009) Removal of uranium(VI) from the aqueous phase by iron(II) minerals in presence of bicarbonate. Appl. Geochem. 24, $1617-1625$.

Albers R., Rehr J. and Zabinsky S. (1992) High-order multiplescattering calculations of X-ray-absorption fine-structure. Phys. Rev. Lett. 20, 3397-3400.

Roden E. E., Leonardo M. R. and Ferris F. G. (2002) Immobilization of strontium during iron biomineralization coupled to dissimilatory hydrous ferric oxide reduction. Geochim. Cosmochim. Acta 66, 2823-2839.

Roden E. E. and Zachara J. M. (1996) Microbial reduction of crystalline iron(III) oxides: Influence of oxide surface area and potential for cell growth. Environ. Sci. Technol. 30, 1618-1628.

Roh Y., Chon C.-M. and Moon J.-W. (2007) Metal reduction and biomineralization by an alkaliphilic metal-reducing bacterium, Alkaliphilus metalliredigens QMYF. Geosci. J. 11, 415-423.

Roh Y., Zhang C.-L., Vali H., Lauf R. J., Zhou J. and Phelps T. J. (2003) Biogeochemical and environmental factors in Fe biomineralization: magnetite and siderite formation. Clay Clay Miner. 51, 83-95.

Rovira M., El Aamrani S., Duro L., Giménez J., De Pablo J. and Bruno J. (2007) Interaction of uranium with in situ anoxically generated magnetite on steel. J. Hazard. Mater. 147, 726-731.

Sakaguchi T., Arakaki A. and Matsunaga T. (2002) Desulfovibrio magneticus sp. Nov., a novel sulfate-reducing bacterium that produces intracellular single-domain-sized magnetite particles. Int. J. Syst. Evol. Microbiol. 52, 215-221.
Sakaguchi T., Burgess J. G. and Matsunaga T. (1993) Magnetite formation by a sulphate-reducing bacterium. Nature 365, 4749.

Sapota T., Aldahan A. and Al-Aasm I. (2006) Sedimentary facies and climate control on formation of vivianite and siderite microconcretions in sediments of lake baikal. Siberia. J. Paleolimnol. 36, 245-257.

Schofield E. J., Veeramani H., Sharp J. O., Suvorova E., BernierLatmani R., Mehta A., Stahlman J., Webb S. M., Clark D. L., Conradson S. D., Ilton E. S. and Bargar J. R. (2008) Structure of biogenic uraninite produced by Shewanella oneidensis strain MR-1. Environ. Sci. Technol. 42, 7898-7904.

Scott T. B., Allen G. C., Heard P. J. and Randell M. G. (2005) Reduction of $\mathrm{U}(\mathrm{VI})$ to $\mathrm{U}(\mathrm{VI})$ on the surface of magnetite. Geochim. Cosmochim. Acta 69, 5639-5646.

Sharp J. O., Schofield E. J., Veeramani H., Suvorova E. I., Kennedy D. W., Marshall M. J., Mehta A., Bargar J. R. and Bernier-Latmani R. (2009) Structural similarities between biogenic uraninites produced by phylogenetically and metabolically diverse bacteria. Environ. Sci. Technol. 43, 8295-8301.

Stadelmann P. A. (1987) EMS - a software package for electron diffraction analysis and HREM image simulation in materials science. Ultramicroscopy 21, 131-145.

Stookey L. L. (1970) Ferrozine - a new spectrophotometric reagent for iron. Anal. Chem. 42, 779-781.

Thompson A., Chadwick O. A., Rancourt D. G. and Chorover J. (2006) Iron-oxide crystallinity increases during soil redox oscillations. Geochim. Cosmochim. Acta 70, 1710-1727.

Ulrich K. U., Ilton E. S., Veeramani H., Sharp J. O., BernierLatmani R., Schofield E. J., Bargar J. R. and Giammar D. E. (2009) Comparative dissolution kinetics of biogenic and chemogenic uraninite under oxidizing conditions in the presence of carbonate. Geochim. Cosmochim. Acta 73, 6065-6083.

Ulrich K. U., Singh A., Schofield E. J., Bargar J. R., Veeramani H., Sharp J. O., Bernier-Latmani R. and Giammar D. E. (2008) Dissolution of biogenic and synthetic $\mathrm{UO}_{2}$ under varied reducing conditions. Environ. Sci. Technol. 42, 5600-5606.

Van Der Zee C., Roberts D. R., Rancourt D. G. and Slomp C. P. (2003) Nanogoethite is the dominant reactive oxyhydroxide phase in lake and marine sediments. Geology 31, 993-996.

Veeramani H., Schofield E. J., Sharp J. O., Suvorova E. I., Ulrich K. U., Mehta A., Giammar D. E., Bargar J. R. and BernierLatmani R. (2009) Effect of $\mathrm{Mn}(\mathrm{II})$ on the structure and reactivity of biogenic uraninite. Environ. Sci. Technol. 43, 65416547.

Viollier E., Michard G., Jézéquel D., Pèpe M. and Sarazin G. (1997) Geochemical study of a crater lake: Lake pavin, Puy de Dôme, France. Constraints afforded by the particulate matter distribution in the element cycling within the lake. Chem. Geol. 142, 225-241.

Wersin P., Hochella, Jr, M. F., Persson P., Redden G., Leckie J. O. and Harris D. W. (1994) Interaction between aqueous uranium (VI) and sulfide minerals: spectroscopic evidence for sorption and reduction. Geochim. Cosmochim. Acta 58, 2829-2843.

Wielinga B., Bostick B., Hansel C. M., Rosenzweig R. F. and Fendorf S. (2000) Inhibition of bacterially promoted uranium reduction: ferric (hydr)oxides as competitive electron acceptors. Environ. Sci. Technol. 34, 2190-2195.

Zachara J., Kukkadapu R., Fredrickson J., Gorby Y. and Smith S. (2002) Biomineralization of poorly crystalline Fe(III) oxides by dissimilatory metal reducing bacteria $(\mathrm{dmrb})$. Geomicrobiol. J., 179-207.

Zachara J. M., Fredrickson J. K., Li S. M., Kennedy D. W., Smith S. C. and Gassman P. L. (1998) Bacterial reduction of crystalline $\mathrm{Fe}^{3+}$ oxides in single phase suspensions and subsurface materials. Am. Mineral. 83, 1426-1443. 
Zachara J. M., Fredrickson J. K., Smith S. C. and Gassman P. L. (2001) Solubilization of $\mathrm{Fe}(\mathrm{III})$ oxide-bound trace metals by a dissimilatory Fe(III) reducing bacterium. Geochim. Cosmochim. Acta 65, 75-93.

Zhang C., Liu S., Phelps T. J., Cole D. R., Horita J., Fortier S. M., Elless M. and Valley J. W. (1997) Physiochemical, mineralog- ical, and isotopic characterization of magnetite-rich iron oxides formed by thermophilic iron-reducing bacteria. Geochim. Cosmochim. Acta 61, 4621-4632.

Associate editor: Kevin M. Rosso 